Historic, Archive Document

Do not assume content reflects current scientific knowledge, policies, or practices. 



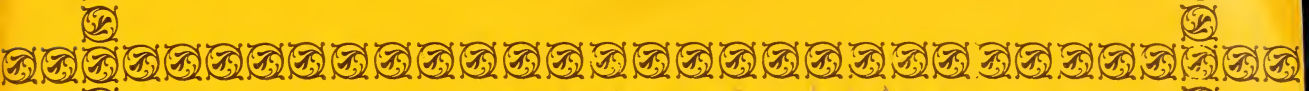

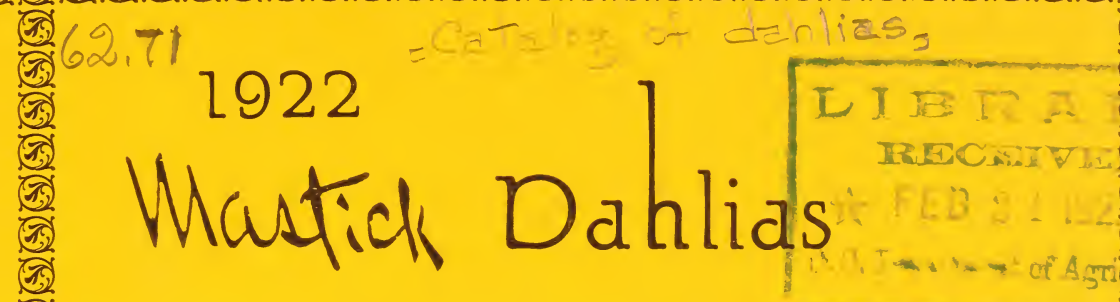

$\nexists^{\text {re distinctly original and famous for their }}$ $\mathcal{A}$ wondrous beauty of form and coloring

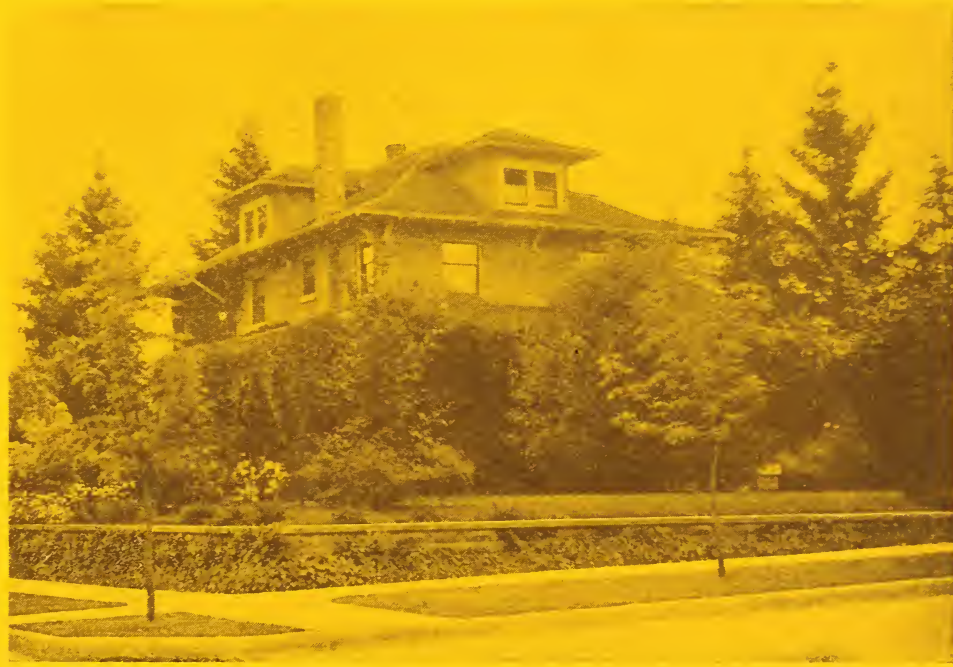




\section{INSTRUC TIONS-INFORMATION}

To those who are unacquainted with the different classes and varieties of Dahlias I would suggest that such leave the selection to me. Send me the amount of money you wish to invest and in return I will send you those that will surely delight. Also my liberal filling of the order will more than be satisfactory.

ORDER EARLY - As orders are filled in rotation-with field-grown roots only-ordering early will insure the reservation of varieties that later may be sold out.

SUBSTITUTION-Orders are filled with rarieties called for, and, unless substitution is asked, I never substitute.

TIME OF SHIP MENT-Unless otherwise ordered, tubers will be shipped after April 15th, by express or insured mail at my expense. Dahlias ordered shipped before April 15th will be sent only at purchaser's risk of dring out, freezing or rotting.

TERMS-Cash with order unless parties are known to me. No goods sent C. O. D. unless 50 per cent of purchase price accompanies order.

GUARANTEE-I guarantee safe arrival of all goods. I guarantee all bulbs and plants to grow and to be true to name, and will cheerfully replace any that fail in either respect.

REMIITTANCES should be male by bank draft, postoffice money order or registered letter. Postage stamps accepted up to \$2.00. Coin should not be sent by letter unless registered.

ERRORS-While my system for liandling orders is as near perfect as possible, ret in the rush of business errors are possible to occur, and I wish to be promptly notified of such and will at once make same satisfactory. Keep copy of your order for comparison.

NAME AND ADDRESS-Remember to write your NAME, POSTOFFICF, COUNTY and STATE; also give STREET NUMBER or P. O. BOX as plainly as possible.

REFERENCE-Bank of Kenton, Portland, Oregon. 


\section{FOREWORD}

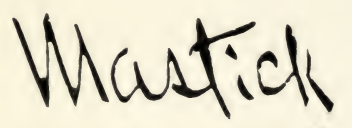

hybrilizing experiments hy Mr. ('. I. Mastick, a merehant of this eity.

We has probably been awarded a larger percentage of Certificates of Merit than any other hyluridizer in this country, and altho his creations are as good as any, and better than mest Dahlias now being offered the publice, he insists that they shall be sold at a price within the reach of all lovers of this beantiful flower, and this accounts for the moderate cost of his proaluctions.

In my list of American and Foreign Dahlias there are several high Iriced varieties, these are the prices of the introducers, and it would be unjust to them, were I to offer them for less money.

All orders receive my personal attention, and are parked with the utmost care, consoguently I guarantee safe arrival and satisfactory results.

Yours very truly,

I. G. TYLER.

I FILL ORDERS WITH PERFECT TUBERS ONLY, NEVER SENDING PLANTS.

The American Dahlia Society's CERTIFICATE OF MERIT is the highest honor possible. Dahlias to be judged are grown under the supervision of Prof. Geo. W. Fraser at the Connecticut Agricultural College, and must receive 85 or more points out of a possible 100 to obtain a certificate. Any variety receiving it is in the perfection class. 


\section{TESTIMONIALS}

My Dear Mr. Mastick:

Long Branch, N. J., Oct. 9th, 1921.

This is in the way of a testimonial to the Dahlia "Glorieux."

It is glorious in habit, foliage, lasting qualities, stem, and above all, in flower. No Dahlia excels it; in very truth, few equal it.

Your mistake in creating "Glorieux", was the price-Five Dollars, which is no price for it; if some others had it-twenty-five dollars would be its price, nothing less.

I sold it orer and over again, many nerer asked the price, they wanted it, bought it, that was all.

I have two hundred varieties, and your most splendid creation is the most superb flower of them all.

Sincerely,

(Signed) JOSEPH FIELD.

Dear Mr. Mastick:

Lexington, Ky., Oct. 6th, 1921.

Your "Glorieux" is fittingly named. The formation of the bloom is the most beautiful I've ever seen in any Dahlia, and its all around qualities are splendid. Visitors to my garden have gasped and raved orer it.

"Maharajah" is as good a Dahlia as one can find, and I am wild orer "Admiral Glennon." Isn't the color, shape and texture something to marvel at?

I think the Dahlias you are producing are the finest that are now being introduced, and I tell my Dahlia friends to write M. G. Tyler, 1660 Denrer Are., Portland, Oregon, when they want the best Dahlias grown.

Yours truly,

(Signed) ALEX. DLNLAP, JR. 


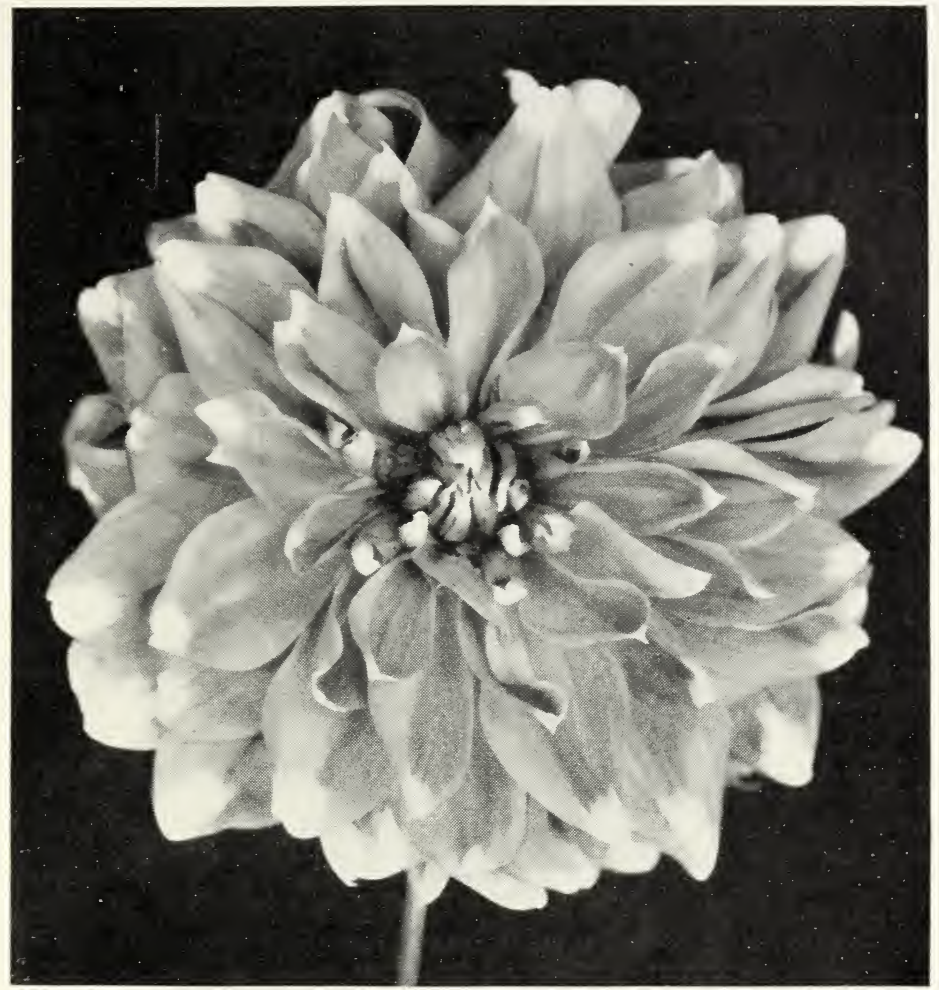

" GLORIELX"

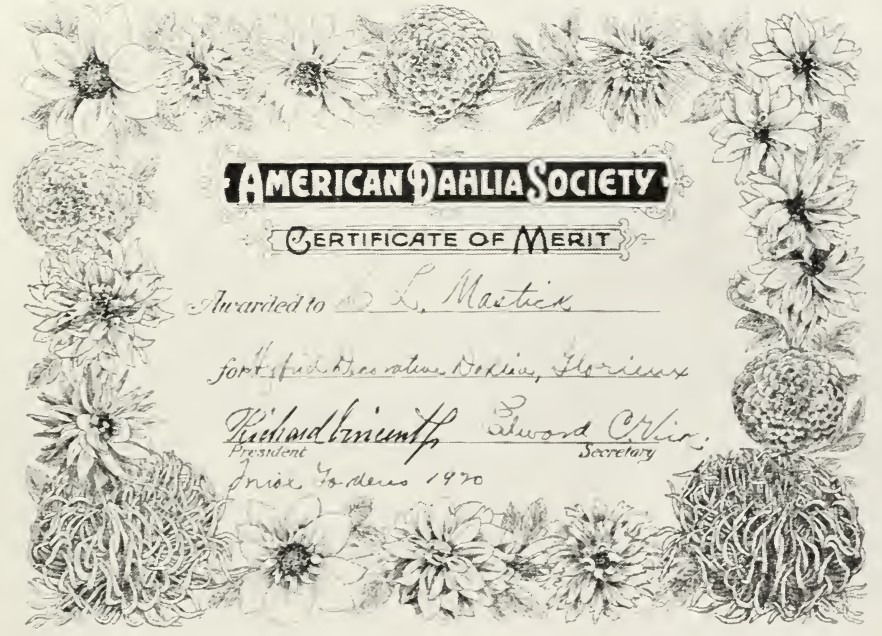




\section{Mastick CREATIONS}

\section{INTRODUCTIONS}

Stock limited on varieties marked $\doteqdot$

ALAN A DALE (Paeony Decorative)-Early in the season this is a decorative, but later is a perfect paeony of wondrous color, and perfect formation. Its florets curl and twist spirally. Size is immense, with long, strong, upright stems. Color is deep orange, suffused Brazil red, but the shades are so blended that from a little distance it is the color of the new shade of Henna with brightest orange gold center. It always attracts the greatest attention.................. \$5.00

CARIBEE (Hybrid Cactus)-A. D. S. Certificate of Merit, Storrs, Conn., 1921. This is a hard flower to describe owing to the peculiar blending of shades, the groundwork being a rich Tyrian rose with lines of cream thru each petal, and lightening to cream at the tips, with cream reverse. The florets are rolled and twisted in an odd manner that enhances the beauty of the flower. A very free bloomer with strong upright stems................................\$5.00

GERALDINE ANTHONY (Paeony) - A very large flower of the loveliest shades of rose pink, from the palest creamy blush in the center thru all graduations of color to a rich rose on the outer rows of petals. The flower is cup shaped, and each petal is distinctly edged rose. The stem is long, strong and upright. Flower is a good keeper and free bloomer ....................................\$3.50

MRS. KATHARINE LANSDOWNE FIELD (Hybrid Cactus) - A bright glowing scarlet distinctly tipped white, with rolled incurved petals. Its graceful flowers are held on long upright stems high above the foliage. This is one of the very few fancy Dahlias that alwars comes true to type. It is a very free bloomer and a great farorite with visitors to

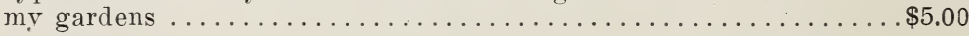

RODERICK DHU (Decorative)-A seedling of Kalif, having a cane-like stem and all the good qualities of its parent, differing from it only in shape and color. It is a salmon scarlet of large size and unique formation, the florets twisting to a point at the tips. A free and constant bloomer, and sure to be a favorite....................

THE LAIRD (Paeony) - A very large flower of rich glowing carmine with velvety sheen. Strong stems and free bloomer. The bush forms a snot of deep but bright color in the garden ................\$3.50 


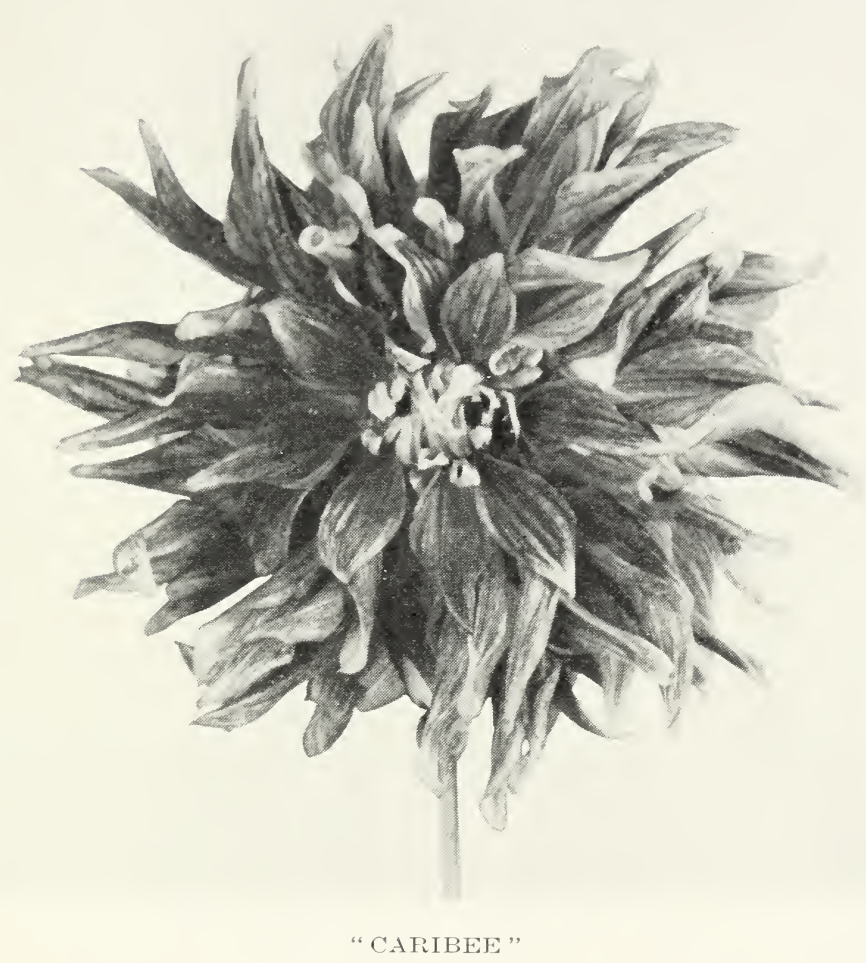

\section{PREVIOUS “MASTICK” INTRODUCTIONS}

slock limited on varieties marked $\dagger$

ADMIRAL GLENNON (Hybrid Decorative) - I seedling of "The Imp." While this Dahlia is not one of the largest, it is so exquisite both in form and coloring that it attracts the instant attention of erervone who sees it. In color it is a rich dark garnet sharing to almost black in the center. The florets are waver and curled, forming a very graceful flower. Its stems are slender but upright and strong enough to bear erect this beautiful Dahlia. To see it is to desire it, and no Dahlia collection will be complete without it ................ $\$ 2.00$

ALI BABA (Decorative) - A larga, full and very deep flower on strong stem. Long (urly waving petals. Color cardinal red white, tipped and blended.

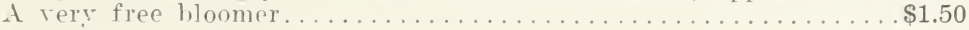




\section{Stock limited on varieties marked $\dagger$}

AMY ROBSART (Decorative)-Received Certificate of Merit at American Dahlia Society's trial gardens, Storrs, Conn., 1919. An immense decorative of a pleasing deep coral shade with apricot reverse. The petals curl and twist in such manner as to show the reverse as much as the front and, curling backwards, make a deep as well as large flower. Strong upright stems, a free bloomer and good keeper. It is the finest decorative of the year, a joy to behold and more than a pleasure to

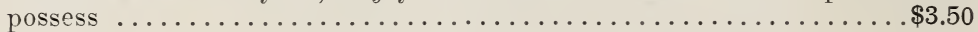

Prof. Geo. W. Fraser, of the Connecticut Agricultural College, says of this Dahlia: "An immense flower on good stem. Worthy of a place in any garden or for exhibition.',

BASKERVILLE (Hybrid Cactus)-Color pure coral on good stem. Large and full with wary petals. Tery free bloomer............\$1.00

BECKY SHARP (Hybrid Cactus)-This I consider a masterpiece, and is undoubtedly one of the very best of Mr. Mastick's creations, being a free bloomer on a particularly good stem. The Ahs! and Ohs! of my visitors expresses the delight this beauty affords. It is a large flower, yellow at base of petals, quickly changing to currant red, with lighter reverse ............................... $\$ 2.50$

CHERRY MALOTTE (Hybrid Paeony) - I introduced this variety in 1918 and sold it out that season. Have just succeeded in replenishing my stock and can supply but a limited quantity for 1922. Color is cherry red with apricot reverse, gradually changing to coral with lighter tips. Center open and petals curl and incurve. Strong stem. A remarkable and decidedly odd flower and a beauty................\$2.00

CORDOVA (Hybrid Cactus) - A seedling of Bodeka, which it resembles in shape, size and habit. Color is pale lavender with picotee edge of heliotrope around each petal. Long, strong stems, but more horizontal than upright. Good keeper and free bloomer................ \$1.00

DOROTHY MAUD (Decorative) - A fine large flower of many rows of graceful and partially folded petals with rather pointed tips. It blooms early and continuously. Color is a Trrian rose and the stem is all that can be asked for in any Dahlia. It is particularly good as a cut flower and will be a farorite......................... $\$ 2.00$

FANTASTIQUE (Orchid Paeony)-This introduces a new type of Dahlia of an odd and fantastic shape. The flower is semi-double with irregular cup-shaped florets, curled and twisted in a manner that gives the appearance of a variety of Orchid. Its color is a deep wine crimson tipped and bordered with glistening white, and it is borne erect on a long, graceful stem. Recommended for Certificate of Merit (highest award), American Dahlia Society, New York, September, 1917....\$1.00

"A very remarkable variety," is Prof. Fraser's verdict on this very odd and attractive Dahlia. 


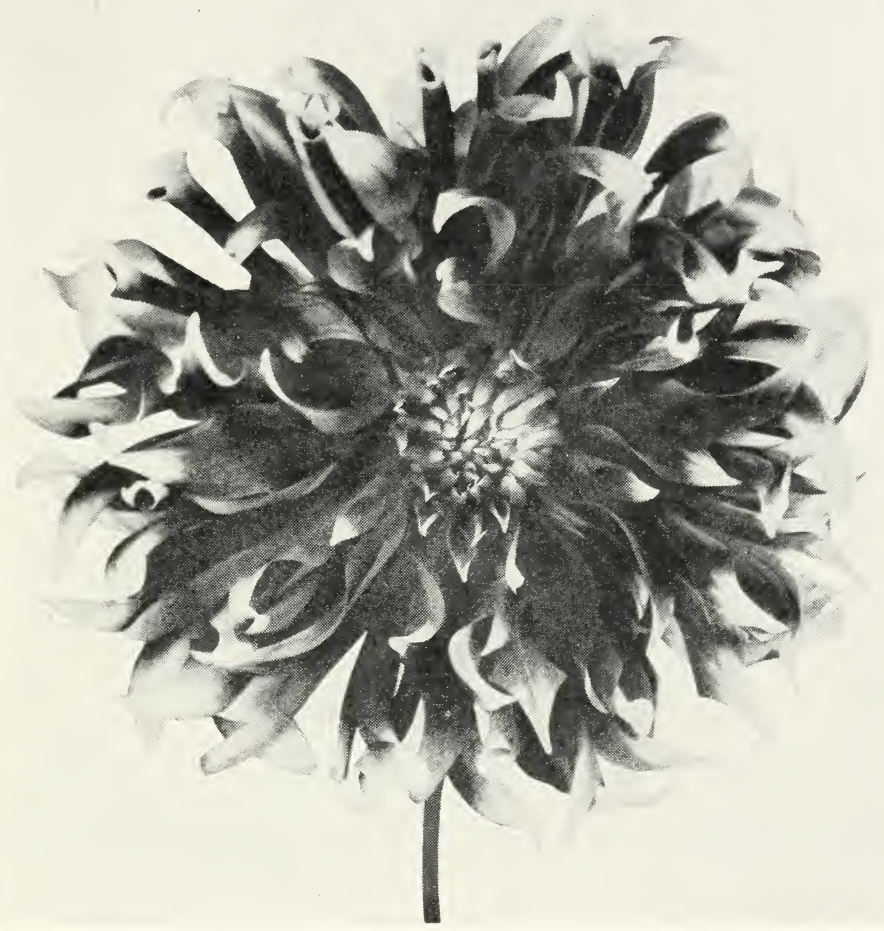

"MRS. KATHERINE LANSDOWNE FIELD"

Stock limited on varieties marked $\dagger$

GEORGE H. MASTICK (Hybrid Paeony)-Large flowers of many wary petals, full to center on strong stems. Color is blackish maroon with currant tips to outer rows of petals. As flower ages it shows a yellow disc around center and changes color to a deep crimson. Remarkably free bloomer and beautiful at all stages. This Dahlia received Certificate of Merit of the trial grounds of the American Dahlia Society, 1919,

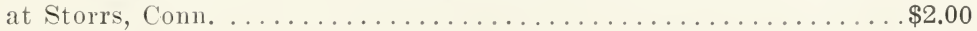

Prof. F. N. Hall, of the U. S. Agricultural Experiment Station, Geneva, N. Y., in his list of meritorious Dahlias, says of this variety, "A wonderful flower.', 
Stock limited on varieties marked $\dagger$

GLORIEUX (Decorative)-Received American Dahlia Society's Certificate of Merit at Storrs, Conn., 1920. It name indicates its French ancestry. It is a flower of wondrous beauty on long strong stems. Color is golden yellow deepening to gamboge bronze in the center, each petal usually tipped white. It is a very free bloomer, and with disbudding will attain a diameter of ten inches. The flower is very full and deep, and is particularly satisfactory as a cut flower. The foliage is as wonderful as the blooms, being an olive green and very dense, forming a graceful bush, the flowers standing well above same..............\$5.00

ILIAMNA (Hybrid Paeony)-Pale salmon pink with yellow shading. Size and shape of Duchess of Brunswick. A free bloomer with strong

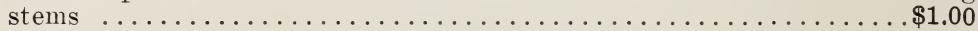

JEANNE FRANCOUER (Hybrid Cactus)-Color, shades of copper and bronze. Flower is composed of very many narrow, curly, twisted petals, and is full to the center. Is a very free bloomer. A remarkable feature of this variety is that it is rarely troubled with any kind of insect pests ............................. $\$ 1.00$

LADY ALLA (Paeony)-Color is a bright scarlet. Long strong stems, carrying flower well above foliage. Large flower and a good keeper. Fragrant and more fragrant as a cut flower than on the bush. Always attracts great attention at my gardens, and is one of Mr. Mastick's best ................................ $\$ 1.00$

In Prof. Hall's list Lady Alla is placed as the BEST IN ITS CLASS.

MAHARAJAH (Decorative)--Large and full with long curly petals. Very strong stems. Color is dregs of wine, lightening to bergundy. Grand flower .................................. $\$ 20$

G. S. Crego, originator of the famous "Crego", giant Aster, says: "For" color, shape, size, stem and free blooming qualities, I consider 'Maharajah' the very best Dahlia I have ever grown.'

MARY JEAN WARNER (Paeony)-Received the American Dahlia Society's Certificate of Merit, 1920. This is one of the Dahlias that has come to stay. A bright golden yellow. Its 18 to 20 -inch stems bear it so erect above the foliage that it can be seen from erery part of the garden. It is very large, with broad and slightly reflexed petals, wonderful as a cut flower, and florists predict it will be a grand commereial as well as an exhibition variety..................... $\$ 3.50$

MANDALAY (Paeony)-Large semi-double flower on long strong stem. Beautiful deep scarlet velvety flower with deeper shadings......\$1.50

-MAYOR OTIS (Paeony) - Color is mulberry red, a peculiar and beautiful shade. Large flower, size and shape of Van Dyke. Free bloomer on long strong stems ........................ 


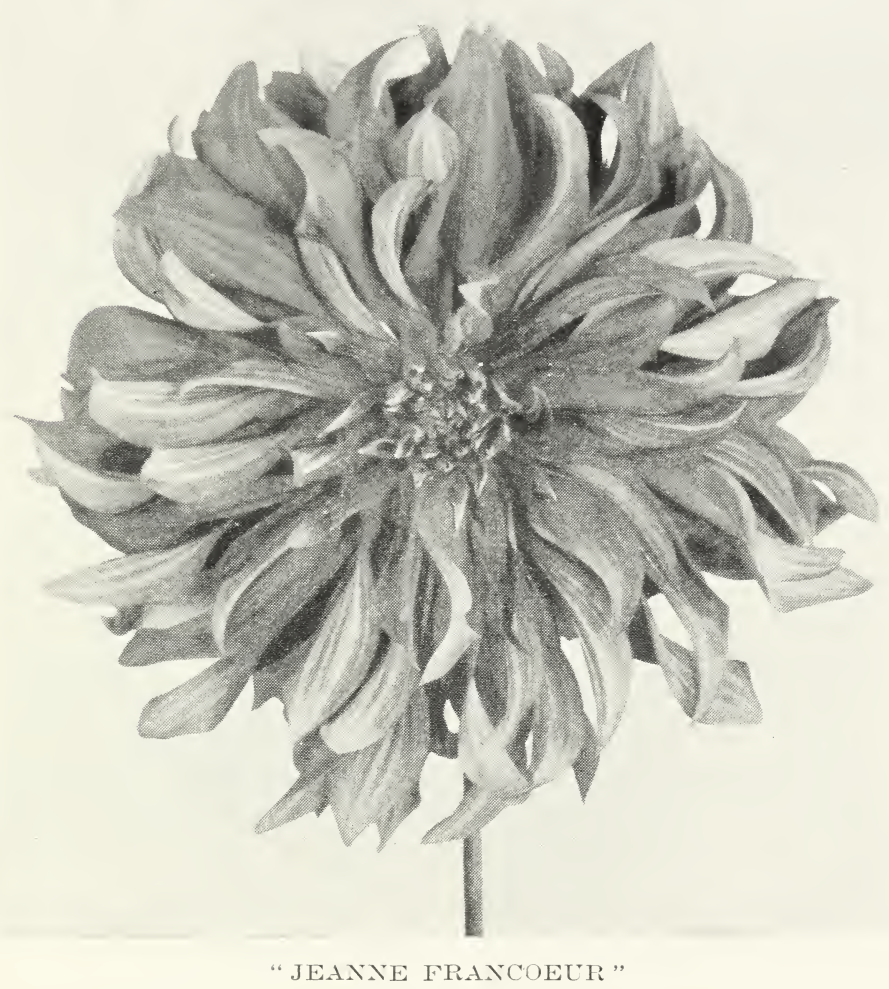

Stock limited on varieties marked $\dagger$

QUENTIN DURWARD (Paeony) - A grand new Dahlia of many rows of graceful curling petals; a soft lemon yellow with the outer rows suffused and marked crimson. A large, fluffy flower, with long strong stems. A profuse bloomer and one sure to be a favorite wherever seen. Received a Certificate of Nerit at the trial grounds of the American

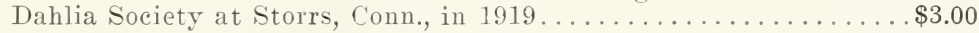

-RHEA MITCHELL (Paeony) - A combination of shades of old rose, maure and cream, making a beautiful salmon pink flower. Large and full with

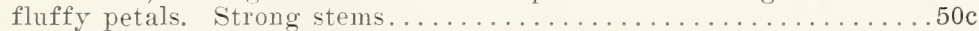

SHELIKOFF (Decorative)-Received the American Dahlia Society 's Certificate of Merit, 1920. Color is deep garnet. Flower is of great substance, both large and deep. Always full to center, with very long strong stems. One of the best.............................. $\$ 20$ 
Stock limited on varieties marked $\dagger$

SIR LANCELOT (Paeony)-Color is blackish maroon. The darkest Dahlia I have yet seen, excepting The Imp. Shape similar to Dr. Peary, but more double and petals stiffer. Strong stems 24 inches long......75c

SISTER THERESA (Decorative)-Received the American Dahlia Society's Certificate of Merit, 1920. Color sulphur white, shading to greenish in center with slightly greenish tips. Large flower with good stem. Dwarf grower. Very free blooming..................\$1.50

SITKA (Decorative)-Color lavender pink. Large full flower on very good stem. Petals curled and reflexed. A very free bloomer and every flower is perfect. At end of season it sometimes shows an open center, but this in no way detracts from its beauty ..............\$1.50

ST. ELIAS (Cactus)-This is the pure white cactus all Dahlia lovers are looking for. It is large, with florets of good substance, slightly clawshaped and incurved. Has a grand habit, fine stem, is a profuse bloomer and good keeper. In fact, it is without doubt the best white cactus

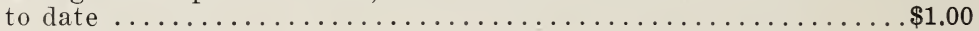

SUNDOWN (Decorative)-Received the American Dahlia Society's Certificate of Merit, 1920. Again we have the Autumn tints so much in demand and so much admired, but in an unusual form. A full decorative with long curly petals only seen in Dahlias of Holland ancestry. A grand upright stem, fine habit of growth, good keeping qualities,. and a long and profuse blooming season makes this a wonderful favorite.\$3.50

TEKLA (Paeony) - Color bright cardinal. Large flower with inner petals curling over center. Strong stems 24 inches in length. A decided favorite and a beauty ...................... \$1.00

\section{GENERAL COLLECTION}

Descriptions of Dahlias are as given by the originators.

Stock limited on varieties marked $\dagger$

$\doteqdot$ ALABASTER (English Cactus)-A flower of purest white. Blooms large and incurved. Plants sturdy and dwarf, carrying flowers erect on stout stems $\$ 1.50$

ALEX KENNEDY (English Cactus) - Deep crimson with extra long strong stems. Very large flower, resembling the F. W. Fellowes in shape. \$1.00

AMPHION (English Decorative)-A large, beautiful variety on good stem. Color pink, suffused heliotrope....................

A. R. PERRY (English Cactus) - A large gold flower with incurved tubular florets. Color old rose tipped with gold, with golden sheen at base. Plants strong and flower stems good. Two first class awards.....\$1.00 


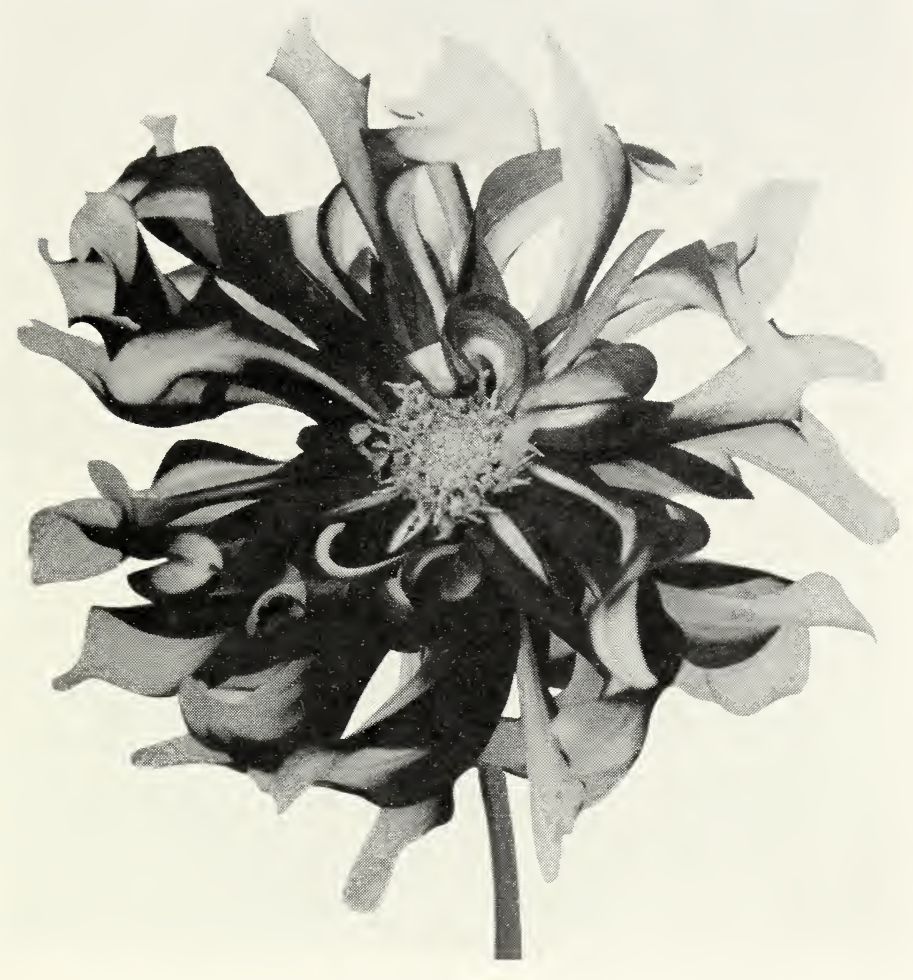

"FANTASTIQUE"

Stock limited on varieties marked $\div$

ATTRACIION (Holland Hybrid Cactus)-One of the best of Holland origin. Large beautiful flowers on long strong stem. Peculiar wayy petals. Color clear lilac rose . . . . . . . . . . . . . . . . . . . . . . \$1.00

AUBURN BEAUTY (English Cactus)--A large incurved variety, petals long and of good substance. Color light bronze passing to yellow in center.

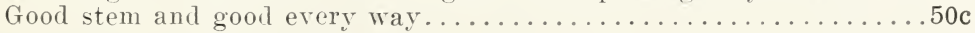

AURORE (Holland Paeony) - Orange salmon, semi-double, free flowering,

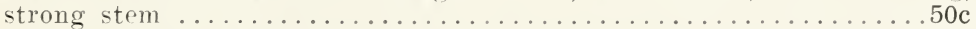

BERTHA VON SUTTNER (Holland Paeony)-('olor salmon pink sliaded yellow. Large flowers held ereet on long stiff stems. The flower is remarkable in form, with petals twister at points most artistically. .50c 
Stock limited on rarieties marked $\dagger$

$\div$ BETTWS (English Paeony) - One of the best English varieties. As large and fine as Cream King. Color a combination of old gold, rose and amber. Long strong stems. A grand flower................\$1.00

BIANCA (Holland Cactus) - A Holland rariety that has attracted great attention and farorable comment. Gigantic size and splendid form, on long strong stems. Color an exquisite rose. Good habit, free bloomer. .75c

BILLIONAIRE, THE (A Stillman Paeony)-This monster paeonr is one of the largest of its type we have erer grown. The color is a beautiful shade of golden orange. A wonderful production, as the flowers are of immense size . . . . . . . . . . . . . . . . . . $\$ 2.00$

BIZARRE (English Cactus) - A wonderfully pretty bi-colored Cactus, the lower half of the florets being of a crimson scarlet, and the upper half pure white. Flowers of large size, incurved and often partially whorled in form. Free flowering and early. Two first-class awards.......75c

BODEKA (English Cactus) - A particularly satisfactory English flower with rather thickish petals. Color pale pinli with white center.......50c

BORDER KING (English Cactus) - Scarlet, with long twisting florets. Fine exhibition flower and one of the earliest to bloom. Very free flowering on strong erect stems. One of the best................

BREAK O' DAY (American Hybrid Cactus) - A full high center decorative, with back curred petals coming up through the flatter ones. Color is clear sulphur yellow shading to sulphur white. Very good.......75c

BRITISH LION (English Cactus)_Color is peculiar, vellowish for the most part, but burnished with red; it is almost tawny in color. Plants are strong and produce huge flowers. . . . . . . . . . . . $\$ 1.00$

†BRUSSELS (English Paeony) -_Soft orange, reverse salmon scarlet, large bold flower on good stem.......................... $\$ 1.00$

CALIFORNIA ENCHANTRESS (California Hybrid Cactus) - A large bloom of good substance. A beautiful shade of pink. Good stem.......\$2.50

CAMBRIA (English Decorative)-Rich pink toning to white center, massive full flower, with broad petals, quite erect on long rigid stems, free,

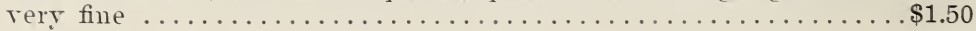

CAPTAIN BAIRNSFATHER (English Cactus) - It is quite usual for people to refer to certain Cactus Dahlias as "those shaggr ones," and this rariety is one of the most pronomesed of this class. Color, red orerlaying orange and rellow, with yellow more decided at center. Plants free, and stems of average length and wiry.............\$1.50

CARMEN SYLVIA Holland Decorative)-One of the latest and finest of Holland introductions. Flowers are of an exquisite shade of salmon, of fine form, borme freely on long stems. Extra fine for cut flower, as well as exhibition................................ $\$ 1.00$ 


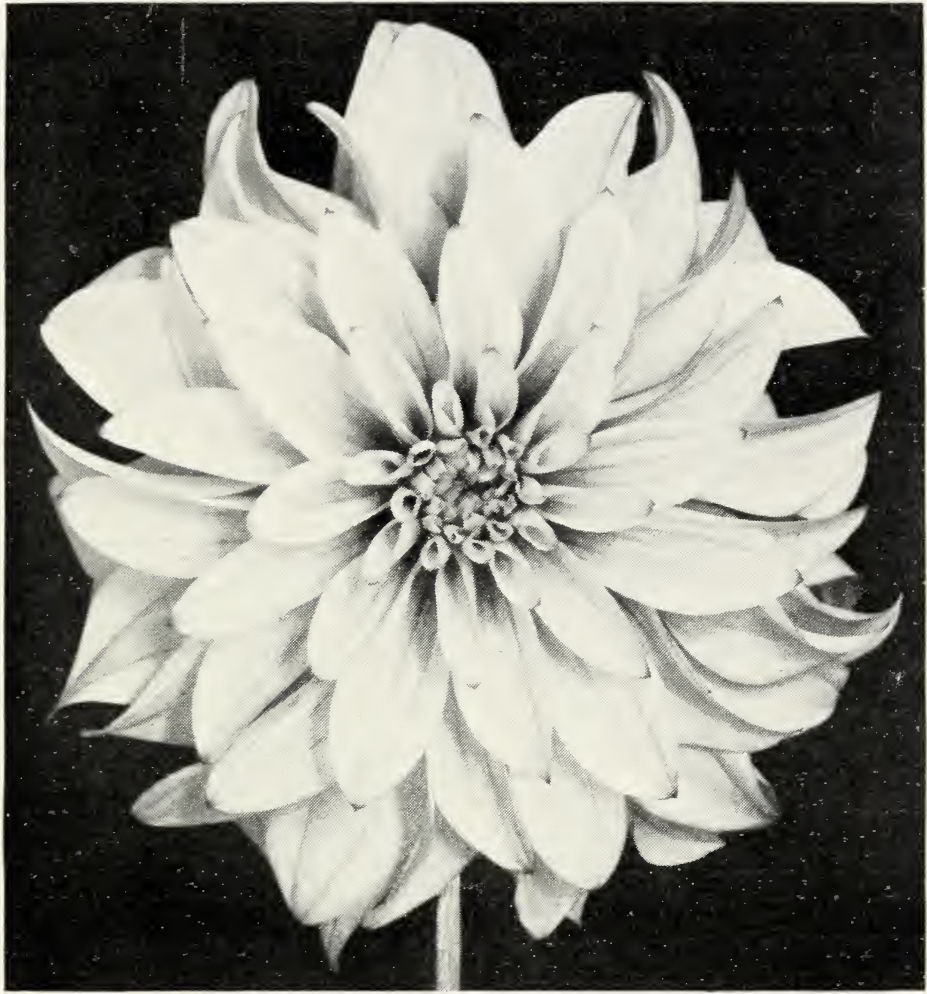

"SISTER THERESA"

Stock limited on varieties marked $\dagger$

CAROLYN WINTJEN (California Decorative)-A very beautiful salmon pink with rose shadings. Large flower with a good stem. A vase of these lovely pink blossoms received First Prize at the California State Floral Society's 1920 Exhibition. Stock limited........... $\$ 2.50$

CATO (English Decorative) - Not a large flower, but wonderful for cutting, as its lasting qualities are unusual. Color soft silvery rose, on long, rigid stems. Very free blooming...................

CHAS. SHERBROOKE (Oregon Hybrid Cactus) - A large flower with curly petals. Color is scarlet with orange reverse. Free flowering on good stems, and keeps well as cut flower. "This beantiful variety is of

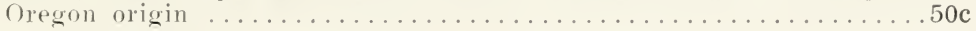




\section{Stock limited on rarieties marked $\dagger$}

CHIEF SEATTLE (Washington Paeony) - An immense flower on long strong stems. Color is a most delicate shade of shell pink, particularly beau-

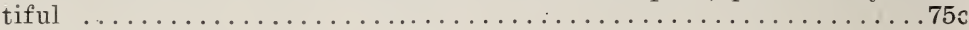

TITY OF PORTLAND (Oregon Paeony)-One of the best Norelties ever introduced. Color a clear deep rich yellow. It has every good quality: immense flowers that are graceful and artistic, held upright on long strong stems that show them to full view; the plants are strong and vigorous and produce their flowers with unusual freedom. This grand Dahlia will become very popular when it is known, as it is a perfect exhibition flower as well as for garden and cutting. This Dahlia won first prize for "The Largest Dahlia" at the recent Palace Hotel Show.....\$4.00

CLAREMONT (California Decorative)-Pale salmon pink, shaded yellow. A beautiful flower, with curly petals, on a very good long stem... \$2.50

COLOSSAL PEACE (American Hybrid Cactus)-A massive Dahlia of the Kalif form and size. Color creamy white at center shading to riolet rose, with lighter tips......................\$2.00

COMPTESSE NADA (French Hybrid Cactus)-Shades of cream and tan, edges faintly flushed lavender. Petals beautifully curved......\$1.00

CONSTANCE (English Cactus) - A rich creamy yellow suffused rosy pink on outer florets; a very attractive color, flowers large, very full and deep, fine center, very long florets moderately and regularly incurved. Good stems. Two first-class awards..................50c

COPPER (California Decorative)-Odd coloring, being copper shading to bronze. Tall growing, free bloomer, good stem..............50c

COPPERFIELD (Holland Decorative)-A very late importation. Color cinnamon with dark center. Trell formed flower on long stiff stems.\$1.00

CREAM KING (English Decorative)-An immense flower on long strong stems. Color is a deep cream. One of the most satisfactory......75c

CURLEW (English Cactus) - Old Rose color, massive full flowers, very long florets incurving right over center, splendid size and shape.....\$1.00

DANDY (English Paeony) - Scarlet crimson flowers on long strong stems $\$ 1.00$

DIANA (Holland Hybrid Paeony)-Crimson with violet reflex. Good stems and is considered one of the "good ones"' in the Holland rarieties..75c

DREAM (Holland Decorative)-Conspicuous salmon shade with amber-like glow. Flower of supreme beauty and perfect form. Long strong stems ..............................

DR. IEVIS (California Decorative) - A decorative of enormous size. Flowers measure 9 to 11 inches in diameter, held erect on long stiff stems; a pretty shade of salmon rose suffused with gold. A rare norelty.... $\$ 1.00$ 


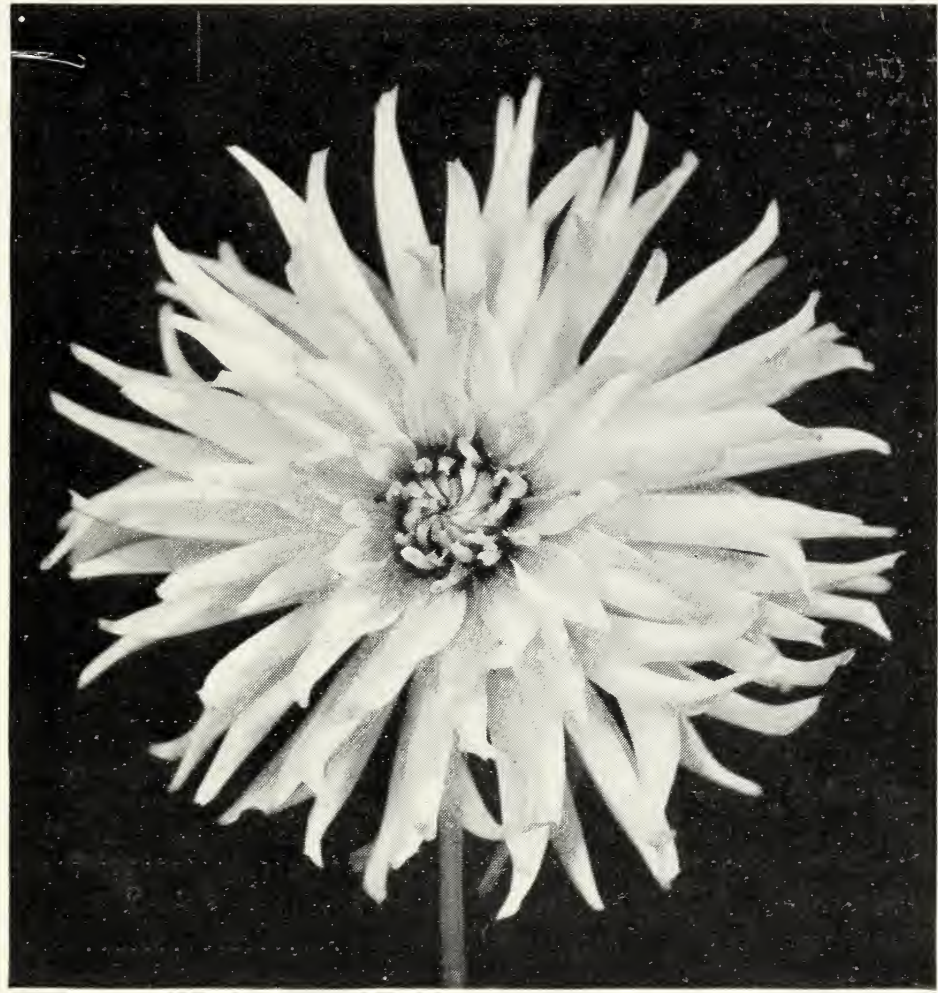

"ST. ELIAS"

Stock limited on varieties marked $\div$

E. CHEVALIER (French Decorative) - White base, bordered garnet. Good

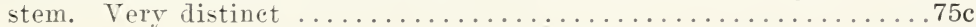

EDITH CAVELL (English Paeony)-An enormous flower on a very long stem. Habit of growth quite erect. Color is old gold, shaded reddish bronze. Think this is the best English paeony of the rear....... \$1.50

F. F. HAWES (English Cactus)-Clear salmon pink on strong cane-like

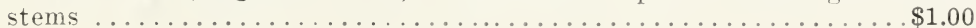

ELECTRIC (English Cactus) -Color lemon yellow with white tips. A very

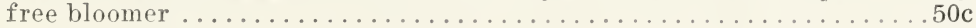


Stock limited on varieties marked $\dagger$

ERIN (English Cactus)-Bright orange red or cinnamon reddish orauge. Flower large, outer florets almost straight, center slightly incurved, strong erect flower stems. Two first-class awards...........50c

ETENDARD De LYON (French Hybrid Cactus) - A French creation by the celebrated Riroire. Color a peculiar and beautiful shade of purple. Petals loose and large. Stem always good...............75c

EXCELLENT (English Paeony)-Color coral, shaded with cardinal. Large

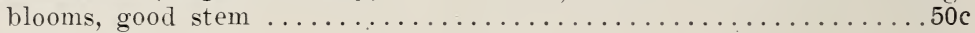

EXMOUTH GLORY (English Decorative)-A medium size Dahlia of very graceful form and lovely coloring, it being bright rellow with orange shading, each petal deeply tipped white. A very free bloomer with a

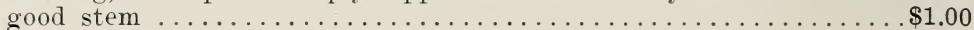

FASCINATION (English Cactus)_Pink shading to white center and base of florets, large bold regularly incurved flower . . . . . . . . . .

FOREST IOMA (A Stillman Paeony)-Deep cerise pink, blotehed and streaked canary yellow, with vellow at center. Petals are finely formed and numerous and curled at points. Verv large and another erect

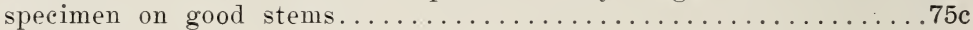

FRANS LUDWIG (Holland Decorative)-A late introduction of an exquisite lavender pink shade, showing a bright pink in artificial light. It is considered one of the finest cut flowers known. Medium size flowers on

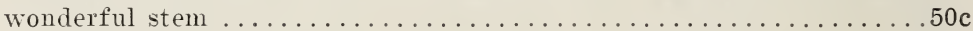

FUGI (English Paeony) - A lovely white flower, with rellow dise in center, with many small petals curving over center..............50c

FUTURITY (English Decorative)-One of the best. Large flowers on long erect stems and freely produced. Color is pink shaded with yellow...75c

F. W. FELLOWES (English Cactus)-This variety produces huge flowers with surprising freedom. Flower stems particularly wiry and plants have a capital strle of growth. Color bright orange scarlet through-

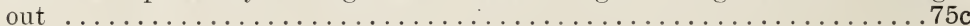

GARIBALDI (Holland Decorative) - One of the best from Holland. A rery full and very large flower with very fluffy petals on a good stem. Color is a bright scarlet. Particularly attractive................

GEISHA (Holland Paeony)-Tellow and red. A most wonderful Dahlia. If you love gorgeous coloring, here you will find it in the orange, red and rellow of this mammoth flower. Geisha flowers are held aloft on long stems in a stately manner, befitting their glorious coloring.....50c

GENL. JOFFRE (French Decorative)-A splendid cut flower. Color is a delicate pink shading to white. A beauty.................. 


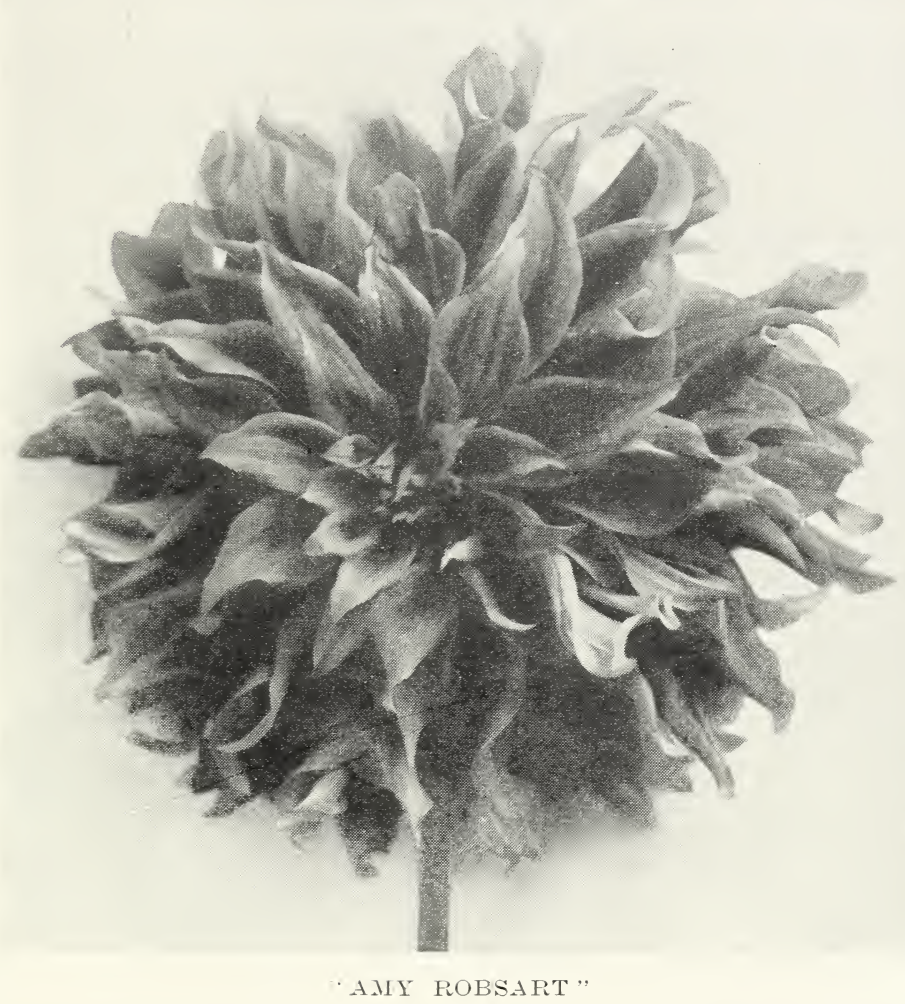

stock limited on varieties marked $\div$

GEORGE WALTERS (California Decorative)-One of the very largest Dahlias on long strong stems. Color is salmon with a golden sheen. This is one of the best Dahlias ever originated in California.......75c

†EO. L. STILLMAN (Hybrid Cactus)--A very large flower on a strong upright stem. Color is deep crimson. Free flowering and quite satis-

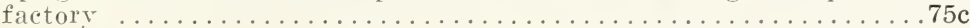

$\doteqdot$ GIANT, THE (English Paeony)_Crimson shaded scarlet. An enormous flower on stems 1 is inches long..................... \$1.00

GLADYS SHERWOOD (California Decorative) - A new pure white variety that is a real giant among dahlias; flowers 9 inches in diameter, without disbudling. In addition to this it is free flowering and the stems are

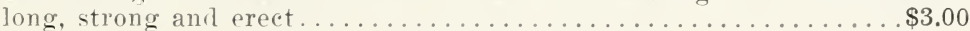


Stock limited on varieties marked $\dot{\dagger}$

GLOIRE DE PARIS (French Show)-A purple crimson flower of immense size, with huge strong stem. A wonderful keeper. Very scarce....75c

GODFREY'S CRIMSON (English Decorative) - A very large bright crimson flower, darker center, on a long strong stem. A very satisfactory

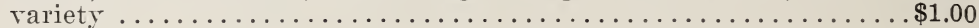

GOLDEN PRINCE (English Paeony) -A beautiful rariety on good stems and of a golden color much wanted in the paeony section. It attracts great attention wherever displayed, and is a very satisfactory flower that will become a general favorite.................... $\$ 1.00$

GOLDEN WEST (California Hybrid Cactus)-A wonderful California Dahlia, free blooming on strong long stem. Color a golden yellow...50c

GOLIATH (English Paeony)-Bright scarlet blooms on long strong stems. Very free blocmer, very large flowers the shape of Cream King.....75c

GREAT BRITAIN (Holland Decorative) - I consider this the best Dahlia ever imported from Holland, and the Holland Dahlias are without doubt the best grown anywhere. Color is a deep lavender with a dark center; the nearest approach to a blue I have yet seen. A free bloomer on a good stem. Really it is a wonder.................\$1.00

GRIZZLY, THE (California Decorative)-A dark maroon red decorativé. Without a doubt this is one of the best and most prolific Dahlias to date. Stems 3 feet long; plants grow 3 or 4 feet in diameter, flowers are extra large and reflexed, which makes it attractive. Awarded prize C. D. S. Trial Garden, 1917. A rare novelty ..................\$2.50

†UUARDIAN (English Cactus) - A giant flower, carried on an upright stem as stiff as cane. Color, a glowing crimson scarlet throughout. Quite the most striking variety we have introduced for some years judged from a decorative standpoint ..................... \$2.00

GWENDOLYN TUCKER (Eiglish Cactus)-An exquisite variety on good stem. Color is pale flesh pink, nearly white at center. A perfect

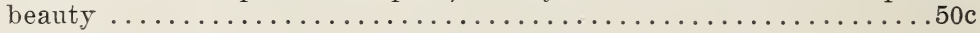

HELEN DURNBAUGH (California Hybrid Cactus)-Delicate blush, deepening rapidly toward the center to an intense, soft glowing pink that defiies description. Blooms medium to large, and to the touch feel like satin. The greatest Dahlia introduced in $1918 \ldots \ldots \ldots \ldots \ldots \ldots \ldots . \ldots 1.50$

HELIO (California Paeony) - A deep bright canary yellow, of enormous size; stems very long and wiry; strong growth and healthy; extremely free flowering, the best yellow of paeony type............. $\$ 2.00$

$\doteqdot$ HI GILL (Washington Paeony) - A very large flower on long strong stem. Free bloomer. Color is golden yellow, reverse of petals, deep reddish

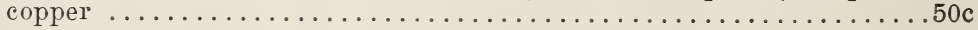




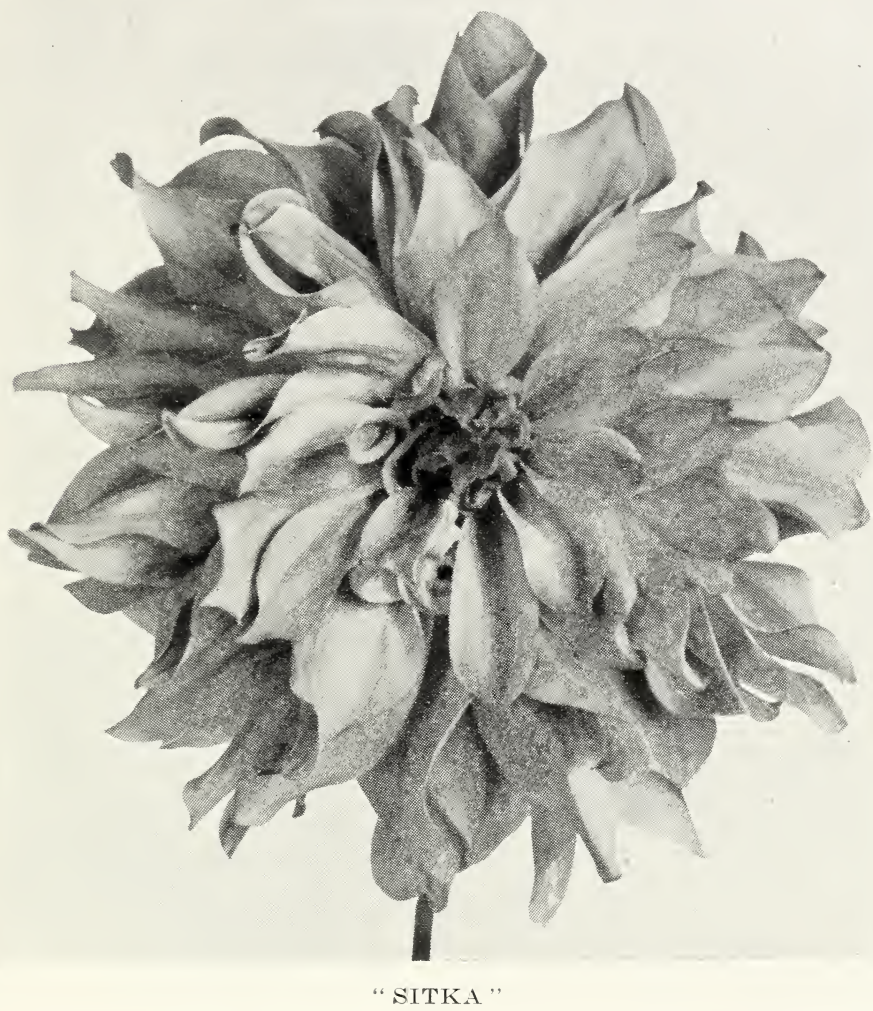

Stock limited on varieties marked $\dot{\dagger}$

HOFFNUNG (Hybrid Cactus)-Light yellow in center, changing to deep rose. Long loose petals and good stem. A farorite............50c

$\doteqdot$ HORTULANIS FIET (Holland Decorative)-Salmon rose, shading to old gold in center. An immense flower on long strong stem......... \$1.00

HUGH McNEIL (English Cactus)-Stems long and stout; free flowering and always full to center. Color beautiful shades of dark pink... 50

†INSULINDE (Holland Decorative)-Colossal flowers of a rich golden orange color. Form of flower everything which could be desired. Admirable for cutting and exhibition. One of the very finest sorts yet produced. It received the second prize for the most artistic flower in the San Francisco Show, losing out only on a few points to a fiftydollar variety. It also won first honors at Los Angeles and New

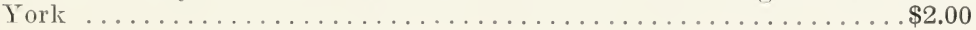




\section{Stock limited on varieties marked $\dagger$}

IVORY WHITE (English Cactus)-Although not a pure white, it is a beauty, being an extremely fine build and shape of flower after the style of $\mathrm{F}$. W. Fellowes. It is a strong grower, good habit, with very long and strong stems. .........................

JACK LONDON-Red decoratives are quite numerous, but no one could resist this, when seen growing in our gardens. Strong, erect growth; stems are long and very stiff. The large blooms are held upright and the color is a distinct, dazzling vermilion scarlet, deepening in the center, $\mathrm{T}$ e. g. c...........................50

†ANE SELBY (California Decorative)-Large flower of delicate mauve pink, of great depth and substance. Good stem and good as cut

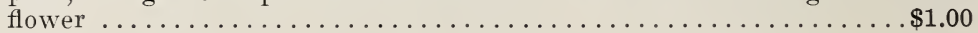

J. M. GOODRICH (an Alexander Decorative)-It has size and beauty. Exceptionally long stems and is free flowering. The coloring is entirely new and wins instant faror. A beautiful salmon pink, each petal effectively tipped primrose yellow. The nearest to an ideal Dahlia we have been able to introduce.........................

JONKHEER BOREEL (Holland Decorative)-An elegant large, showy flower. The color approaches that of the King of Autumn, one of Holland's best .......................... $\$ 1.50$

JULIAN (English Cactus) - Flesh pink, toning to white center. Large flower incurved, narrow florets and good center, and good stem .......\$1.00

JUSTICE BAILEY (Colorado Hybrid Cactus)-A Colorado variety which created a sensation in 1916. Color rich glowing pink, shading a little lighter toward center. Large flowers on good stems...........50c

KAKADEE (Paeony)-A Scottish creation. A dwarf growing variety, with large flowers on good stems, carried well above the foliage. Color pale yellow center, passing to white at tips. Particularly fine.........75c

TALIF (Hybrid Cactus)-A wonderful and beautiful flower of pure scarlet, carried on a very long and strong stem. Remarkably free bloomer and particularly good as a cut flower. It is certainly a prize........50c

KENILWORTH-An incurved cactus of good size. Color is deep amethyst for lower half of petals, balance to tips is pure white. When exhibited it attracts unusual attention owing to its peculiar beauty........75c

KING ALBERT (Holland Decorative)-Broad twisted petals, forming very large flower. Color rich purple. Very distinct and a fine thing. Novelty from Holland .......................... $\$ 1.00$

KING OF THE AUTUMN (Holland Decorative)-The pride of Mr. Hornsveld. The shade is quite new, buff yellow suffused terra cotta. Stems very long and strong, wonderful keeper as cut flower. Very free bloomer. Five highest awards........................ 


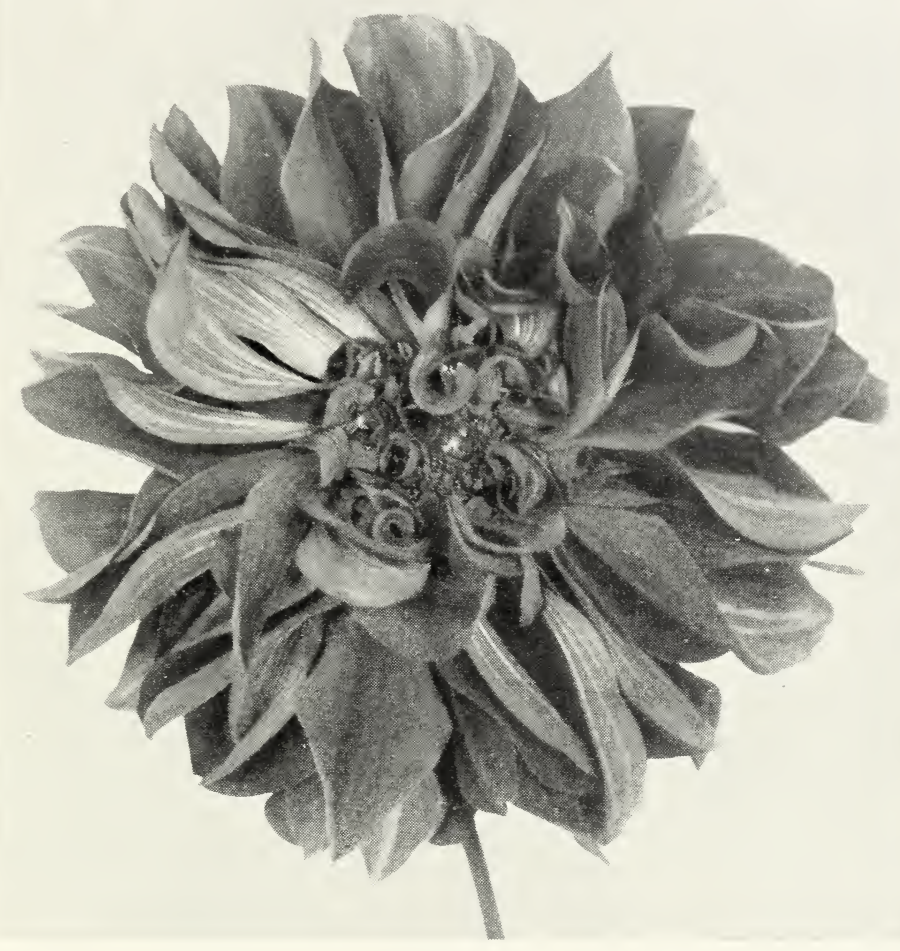

" TEKLA,

Stock limited on varieties marked $\div$

$\doteqdot$ KING OF COMMERCE (Decorative)-Straight, strong petals, attractively arranged. Color, a rich Tango, beautifully lighted Old Gold and Orange; iridiscent under both artificial and sunlight. Size 5 to 6 inches. Stem 1s to 36 inches. Season, early to late without intermission. Wonder-

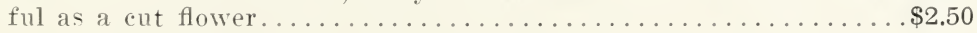

$\div$ KIFFIN ROCKWELL (French Decorative)-Very, very large full flowers. Outside petals rich bronze. Inside petals bright golden yellow. Sometimes tipped white. A very rare, beautiful Dahlia...........\$1.50

TLADY HELEN (Hybrid Cactus) - This is a fine striking variety standing erect on long stems with large, well-formed blooms. The color is a peculiar bronzy pink with suffusions of areamy white rumning through it . $\$ 3.00$ 
Stock limited on rarieties marked $\div$

LA FAVORITA (California Hybrid Cactus)-This splendid new rariety is a beautiful brilliant salmon, shading from a dark reddish salmon in the center to salmon pink at the twisted points. Form perfect, showing a full center, even late in the season. Each bloom carried on a strong

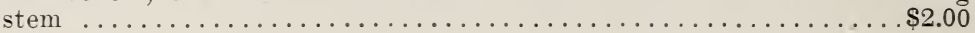

LATONA (Holland Paeony) - A buff rellow semi-double flower. Very free bloomer and very good stem. Tery attractire..............75c

-LAURA BARNES (a Colorado Paeony)-Beyond question one of the grandest paeony Dahlias ever introduced. Only words of praise hare come from those who grew the rariety last season. The immense orange red flowers are pleasing to all. It is today one of the most popular Dahlias

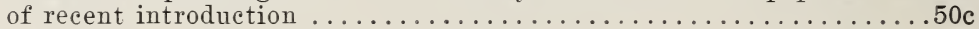

LAVINIA (English Cactus)-While this norel cactus is not new, I do not thing it is so well known as its beauty demands. In form it is unlike any other cactus, its florets being spirally twisted, making a very graceful and artistic flower. In color it is uniquely described as coppery red to madder crimson. The stock of this lorely Dahlia is rery scarce in this country ..............................

LEO XIII (Holland Paeony)-An extremely large Holland variety that is always good. Color clear bright yellow. Stem rery good and it is a constant bloomer. Sure to be satisfactory................

†LIBRA (English Paeony)-Bright roš red, grand habit, free flowering with extra long stems. A farorite................... \$1.00

LIBERTY (English Paeony)-Well known as one of the finest known Dahlias. Color is salmon scarlet, long stemmed and free bloomer...50c

†LORD KITCHENER (English Cactus)-This exceedingly free flowering rariety, in color a lovely shade of reddish salmon, produces perfectly shaped, finely quilled blooms, borne on long, rigid and upright flower stems, and is excellent for either exhibition or garden effect. This superb novelty has received two first-class awards...........\$1.00

MADONNA (English Decorative)-Flowers are of the hybrid cactus type, and though bold and large, are not coarse, for by the graceful arrangement of the semi-curled and twisted petals a distinct and charming character is obtained without stiffness. The blooms are often orer 8 inches across, and the irory white petals, which glisten, are so numerous that high, full centered flowers can always be expected. The habit of growth is compact and perfect. It is a very free bloomer and the flowers are borne on long stiff stems and last well for many days when

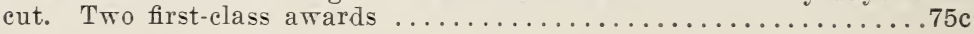

MAGNIFICENT (California Cactus) - A flower of fine form and immense size, coming 8 inches in diameter without disbudding. The color is difficult to describe, the ground color being oriental buff, orerlaid with silvery rosy salmon. A wonderfully free bloomer.............\$1.50 


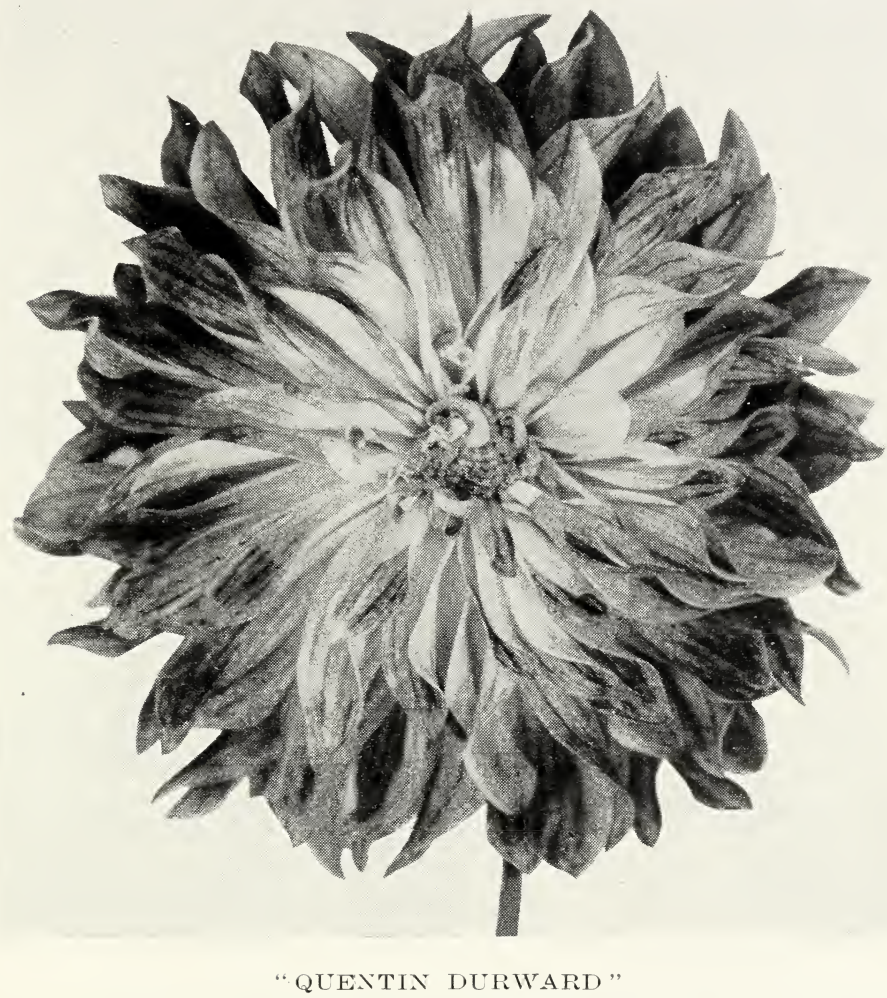

Stock limited on varieties marked $\dagger$

MAPLE LEAF (Washington Paeony)-A good size graceful paeony with long stem; colors of the maple leaf touched by frost; most gorgeous

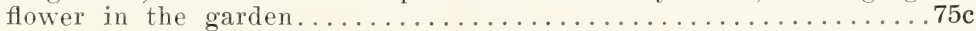

TARABILIS (California Decorative)-Yellow overlaid with deep red;

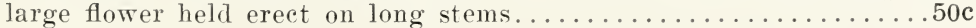

MARCELLA (Decorative)-A delightful clear, soft pink, variety that is bound to become a great favorite with everyone, especially florists. A wonderfully free bloomer on long, individual stems, that hold the blooms rigidly erect. Very perfectly formed and is second to none in keening

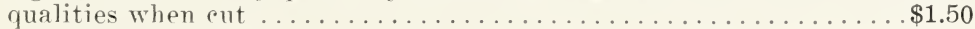




\section{Stock limited on varieties marked $\dot{\dagger}$}

MARY C. BURNS (California Decorative)-One of the best of recent California introductions. Color is a combination of red and old gold, the outside of petals being old gold and the reverse a dull red. The stem is particularly good. It is a free bloomer and every blossom is perfect. A wonderful exhibition and garden variety .............\$3.00

MELODY (English Cactus)-One of the most distinct, color being clear yellow for hali the length of the florets, balance pure white. Stems

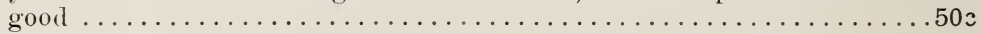

MEYERBEER (Paeony)-One of the largest flowers in commerce. Color is a dark cardinal with purplish center. Long strong stems. This variety always attracts great attention from Dahlia lovers............75c

MILLAIS (English Paeony) - A very beautiful flower, color creamy yellow, suffused pink. Good stem, free bloomer.................50e

MILLIONAIRE, THE (a Stillman Decorative)-A monster Dahlia, standing erect on a strong stem. Color is light lavender lightening to white in center .............................. $\$ 1.50$

MILTON EDWARDS (California Hybrid Cactus)-An entirely new shade, which might be called henna. It is of very odd form and the flowers are very large. The stems are as good as it is possible to be and, all in all, it is a very wonderful Dahlia and one that should be in every collection

MISS JUDD (English Cactus) - A model Dahlia, both as regards plants and flowers. Color lemon yellow at tips and base tinged and blended with shades of pink. Flowers are globular shape, more than usually incurved and claw-like. Very free flowering on good stems. Two first-class awards $50 \mathrm{c}$

$\uparrow$ MISS STREDWICK (English Cactus)-One of the finest Cactus Dahlias yet introduced. Color, soft yellow at base, quickly changing to deep

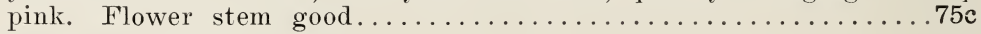

†MONDSCHEIBE (Paeony)-Here we have an immense clear yellow on a good strong stem that is a pleasure to possess..............50c

MME. BUTTERFLY (American Hybrid Decorative)-The greatest novelty of the season. Flowers of wonderful grace and color combinations of violet rose shading darker at tips and blending to a deep golden yellow at base of petals. The long, rather narrow, pointed petals twist, show. ing a rosy magenta reflex, making it very unique........... $\$ 2.00$

MME. E. P. DE NORMANDIE (California Cactus)-Silvery pink shaded lilac. Large flowers of distinct appearance. Fine for cutting.....\$1.00

IMME. VARD (French Paeony)-One of the largest and most striking in this class. Color is currant red shading to yellow in center. Good stems.50c 
Stock limited on varieties marked $\dagger$

$\div$ MRS. A. COBB (English Decorative) - A large flower on long stems. Color, soft flesh pink. Quite satisfactory.................\$1.00

-MRS. ALFRED HARVEY (English Decorative)-This will rank with the best we have ever had the pleasure of offering. A large full flower, with incurved florets gracefully arranged, and a beautiful color, light salmon pink, with darker shading at base of floret. Plants are dwarf, dark foliaged, and carry the flowers upright, on strong wiry stems. This variety passed the $N$. D. S. floral committee's serere standard, namely, perfect flowers on strong stems..............\$3.50

†MRS. ADDISON PRATT (American Hybrid Decorative)-Flowers of immense size on good stems. A great exhibition variety, with petals long and twisted. A beautiful blending of violet rose and deep buttercup vellow ................................ $\$ 2.50$

MRS. CARL SELBACH (California Decorative)-American Dahlia Society's Certificate of Merit, 1919. Immense lavender pink blooms on especially long strong stems. A perfect exhibition as well as cut flower..... \$3.00

MRS. C. COOPER (English Cactus) - One of the finest Dahlias I have yet seen, flowers being of immense size, on good stems, and a free bloomer. Color is cream, the outer petals lightly suffused salmon........75c

MRS. D. B. CRANE (English Cactus)-Purest pearly white, the flowers being of good size, moderately and evenly incurved in form, and ideal center, stems long, strong and erect. Unanimously awarded certificates by the Joint Committee, and judged the best new Cactus at the $\mathrm{N}$. D. S. Show ............................ \$2.50

MRS. DOUGLAS FLEMING (English Cactus)-Without doubt one of the best whites. Very narrow, incurved florets, and so numerous as to make monster flowers. Extra free and constant; erect stem..........50c

MRS. EDNA SPENCER (California Hybrid Cactus) - A new introduction. A flower of delicate and exquisite shade of orchid pink. Very beautiful and of good formation and stems. Received certificate of merit at the Trial Gardens, San Rafael, California, 1917. A lasting cut flower of unusual color. This is one of the finest of Mrs. Edna Spencer's pro-

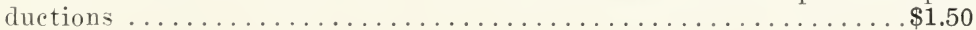

MRS. HERBFRT BLACKMAN (English Cactus)-No longer can it be said that Cactus Dahlias are weak stemmed. This is another variety with a splendid stem, long, stiff and upright, earrying flowers of good size and evenly incurved shape. Color pretty rosy pink on older florets, then lighter to blush, and finally white at center. A cactus useful for any purpose, and in many respects a decided adrance........... \$1.00

MRS. JACK GREEN (California Paeony) - A very large and full flower on a strong stem. Color a beautiful shade of rich scarlet. A California Dahlia that the originator may well be proud of ...........50c 
Stock limited on varieties marked $\div$

MRS. JESSIE SEAL (California Paeony)-One of the best of recent California introduction. Good plant, good stem and good in every way. Flower of largest size and color, a beautiful shade of salmon pink. .\$1.00

MISS NANNIE B. MOOR (California Hybrid Cactus)-Rosy lavender pink, large, well formed flowers, very full and double, strong upright habit, one of the best, won the first prize at the Los Angeles Dahlia Show, 1917, for best Dahlia shown by amateur...............50c

MRS. MARGARET STREDWICK (English Cactus)-Far and away the finest Dahlia we have ever raised, and one combining so many good points that we are in no danger of exaggerating its merits. The coloring is a combination of tints and pinks, softening and deepening at tips and base. The form as perfect as possible, and what is more remarkable, the plants have a grand habit, with strong, stout, upright flower stem. In fact, as grown with us, this is the Cactus Dahlia we have been working for as raisers for many years. Originator's description . . . . \$2.00

MRS. WARNAAR (Holland Hybrid Cactus) - A magnificent Holland variety on good stems. Color a very pale shade of pink. An exquisite

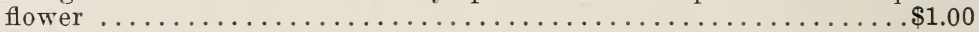

MRS. W. E. ESTES (California Hybrid Decorative)-A very fine new snow white Dahlia of much merit. Broad and long, pointed petals, forming a flower of great size. This is easily our best white Dahlia to date $\$ 1.50$

†MRS. RICHARD LOHRMANN (California Hybrid Cactus) - A pure golden vellow Hybrid Cactus Dahlia of immense size, broad, curly petals; flowers high above the foliage, on long upright stems; excellent cut flower and very floriferous, the best yellow Dahlia to date. Awarded Gold Medal for the best Seedling Dahlia, growing at the Panama-Pacific International

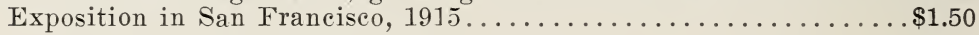

NAIAD (Colorado Paeony) - The plant is all that could be asked in a sturdy, symmetrical growth, attaining a height of 6 feet. Blooms very freely on strong stems of remarkable length. Color a tinted cream pink. Beautiful by day and simply grand under artificial light.......75c.

NEVADA (California Decorative) - A large white, the shape of Beloit. Good stem and free bloomer....................\$1.00

NEW MOON (California Hybrid Cactus) - A hybrid cactus type, color canary yellow tipped white. A very free bloomer, straight stems and it possesses all good points both for exhibition and garden work...\$5.00

NIBELUNGENHORT (Hybrid Cactus) - A large flower on a good stem. Color salmon rose with golden suffusion................50c

NOBILIS (California Decorative)-A wonderfully beautiful flower, one of California's best. Color bright scarlet, edged and tipped white. Strong, upright stem. Free bloomer......................\$2.50 
Stock limited on rarieties marked $\dagger$

NORA LINDSAY (English Paeony)-One of the largest of this type. A free flowering variety. Dove color, suffused pink, with mauve reverse ................................... . . . . .

NORMAN (English Cactus)-Blooms are large and of the finest quality. Color is scarlet shading to orange. Very satisfactory.........75c

OCEAN SPRAY (Oregon Decorative) - A large creamy white flower on long strong stems. Very full flower that keeps remarkably well when cut. Free bloomer and very satisfactory in every way. One cannot make a mistake in planting this favorite................\$1.00

†LD GOLD (English Paeony)-Deep golden amber, very large and very free on particularly good stems. One of the very best...... \$1.00

ORIANA (English Paeony)-An incomparable flower of rare beauty, on long strong stems. Color is pure rose. It is a free bloomer and no

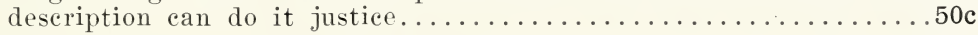

†OSAM SHUDOW (California Decorative)-Color a beautiful shade of old rose, slightly suffused lilac, shading to yellow in center. Blooms usually nine inches or more in diameter. Stem particularly good......\$5.00

PAUL GRAMPEL (Holland Decorative)-Brilliant scarlet. Best of this class. Perfect form. Fine for cut flowers.................75c

TPATRICK O'MARA (Decorative)—The sensation of the Dahlia Show of the American Dahlia Society held in New York City last September. The flowers are 8 inches in diameter and borne on long, strong, erect stems. They are firmly set at right angles to the stems. The color is an unusually soft and pleasing shade of orange-buff, slightly tinged with rose. One of the most lasting cut-flower dahlias. Received American Dahlia Society's Gold Medal for best new variety for $1920 \ldots \$ \$ 3.00$

PEARL RUGGLES (California Paeony)-A gem from the Santa Cruz mountains. Color is carmine rose shading to light pink at outer edges of petals. A wonderfully beautiful flower, carried well above foliage on strong stems. I consider this the finest paeony erer originating in California ................................ \$2.50

PENNANT (English Cactus) - This was considered our best Cactus for 1919, and the flowers (which received the award), arranged in a rase, without wires or any support other than the stems as cut from the plants, were certainly among the finest we have ever exhibited. The form is perfect, of the pronounced incurved type, and the color a beautiful deep yet clear coral.................. \$2.50

PHENOMENAL (English Cactus)-This Dahlia phenomena is totally distinct and unlike any cactus variety yet raised. Flowers are large and florets long and ribbon-like; these incurve to such an extent that they at last form a tangled mass more like a certain Japanese Chrysanthemum than a Dahlia. Color is pale shades of salmon with yellow at base and a decided yellow at tips. Flowers derelop slowly, but last well 
Stock limited on varieties marked $\div$

PIERRE LEBLOUD (French Decorative)-Many Dahlia fanciers say that this is the most beautiful and satisfactory of all decoratives. Flowers are of large size on long strong stems. Color is a deep cardinal, regularly tipped white. It attracts great attention and praise wherever

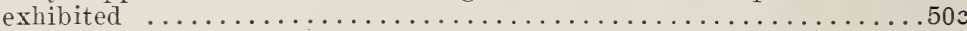

PIERROT (English Cactus) - A unique and striking variety, the color being amber, boldly tipped with pure white. Plants are of splendid habit and the flowers are vers large. Two first-class awards...........50c

POLARIS (California Decorative)-The best pure white Decorative ret produced. Flowers of immense size and perfect form. Good stem...\$2.00

POLAR STAR (English Decorative)-The purest white Dahlia of rem urkable beauty. Flower is large and full and carried on 18-inch stems. For a white Dahlia it is unsurpassed both in appearance and free blooming ................................

PRESIDENT WILSON (English Decorative)-Originated by Test of Brentwood, England, who describes it thusly: "It is without doubt one of the best decoratives ever offered-habit, freedom of flowering, size of flowers and color all that can be desired, the latter being a brilliant

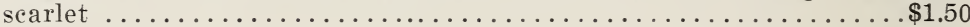

PRIDE OF CALIFORNIA-A large red decorative that cannot be beaten; very large flowers, held on extra good stems, very prolific and an exceptionally good keeper. Fine for garden and exhibition. Awarded second

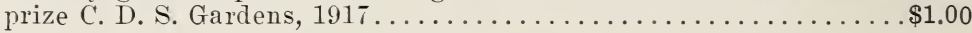

PRINCE ALEXANDER (French Decorative)-Surely a prince among Dahlias. A very large flower held erect on long strong stems. Beautifully shaped and color is shades of cream and tan flushed maure rose .............................. $\$ 1.50$

PRINCESS MARY (Holland Paeony)-Vivid light pink, margined blush. Very showy. Carries a mass of flowers on strong stems..........75c

PRINCESS PAT (California Decorative)-This beautiful new Dahlia is a soft old rose in color, is very large, blooms averaging from eight to ten inches across, and is of great depth. It is borne on long, stiff stems; has a splendid habit and good keeping qualities.........\$2.00

QUAKER CITY (Hybrid Cactus) - In this fine new Cactus Dahlia each petal is supplemented with from three to six narrow pointed petals, showing up through the flower, making a very attractive and artistic flower, of good size, borne profusely. Color primrose vellow............\$1.00

QUEENIE (English Decorative)-Golden amber tipped salmon red. Large and almost globular flower. Free bloomer, with good stems......\$1.00 
Stock limited on varieties marked $\dagger$

QUEEN OF THE ROSES (Holland Decorative)-The best decorative imported from Holland to date. Flower is large and the stem is long and strong. Color is an exquisite shade of Venetian pink. It is unsurpassed as a cut flower and attracts great attention in the garden. It is really

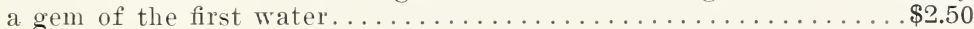

RADEN KARTINI (Holland Decorative)-Salmon shade with lilac and mauve. Large flower, strong stems, very firee bloomer......... \$1.00

R. C. UNWIN (English Cactus) - A large, gracefully incurred flower of reddish salmon, suffusing to yellow at base. Very satisfactory.....502

REALIZATION (California Decorative)-It is a pure golden yellow of immense size, perfect form and splendid blooming qualities. Flowers are held well above the foliage on strong wiry stems. This Dahlia received a Certificate of Merit at the trial gardens of the Dahlia

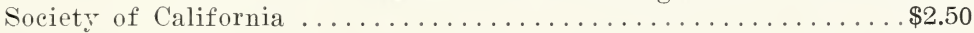

RHEINISCHER FROHSINN (Hybrid Cactus)-An oddly beautiful variety that is a joy to behold. The center is cream, changing to a carmine rose. Its odd shape, combined with this coloring, makes it very

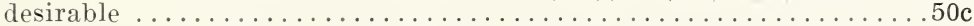

†ROSA NELL (California Decorative)-The color is a clear bright rose, the flowers are large, and I consider it the best shaped Decorative Dahlia I have seen, coming perfectly full and double until frost; good stems and habit, if I could have but one Decorative Dahlia this would be my choice, as the color is a rare one in dahlias, and attracts immediate attention, while the form cannot be surpassed........... \$7.50

ROSE GEMI (Holland Decorative)-A very handsome flower of delicate pinł. Very free bloomer on stout stems..................

ROWENA (English Decorative)-Fawn suffused salmon, reverse and center tinted violet. Fluted petals. Large full flower on long strong

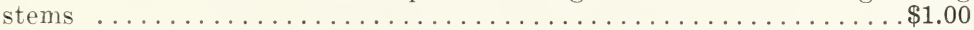

RUTH C. GLEADELI (California Hybrid Cactus)-A fine hybrid of sunburst shades; soft yellow shading to pink on the outer petals. Good stem, large size, excellent formation, and a free bloomer.........75c

RUTH LATIMER (California Paeony)-Color two shades of lavender with white stripes on yellow base. Good stems and very early to bloom. $\$ 1.00$

$†$ RUTH VAN FLEET (Hybrid Cactus) - Clear light canary yellow. This is without doubt the finest yellow Cactus Dahlia ever introduced. The stems are extra long, often measuring 16 inches. The flowers are extremely large measuring from 6 to 81,2 inches in diameter and are held perfectly erect on its stiff, long stems. Hybrid Cactus. It should be seen to be appreciated ....................... \$2.50 
Stock limited on varieties marked $\dot{\dagger}$

†SALVATOR (Holland Paeony)-Deep rose pink, long stems. A high stand-

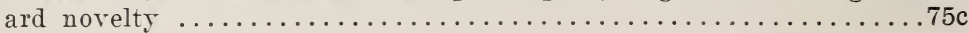

SAMMIE (American Decorative) - The largest ball-shaped yellow decorative Dahlia grown. Color clear deep primrose yellow; of good substance on strong stems ............................

SEAHORSE (English Decorative)-Golden yellow, tipped pure white, hybrid, Cactus type, fine habit, very free, wonderful stems.......... $\$ 1.00$

SEARCHIIGHT (English Cactus) - A yellow form of Miss Stredwick. Flowers are large and beautifully incurved, florets narrow......50c

SELMA (English Paeony)-Very pale pink. Narrow petals curving backward. A rery beautiful flower on good stem...............50c

SENTINEL (English Cactus)-A grand variety, producing huge flowers on good stems. Color for most part a shade of deep rose, but at the base there is a disc of white, which prettily relieres and enhances the darker

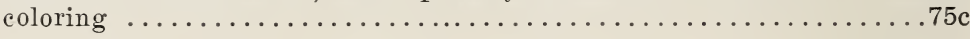

†SERBIA (English Paeony) - A beautiful variety, being rose with white edges and tips, bourne on a long strong stem.............\$1.00

†SHUDOW'S LAVENDER (California Decorative)-A rery large bloom of silvery lavender slightly shading to white. The stem is perfect, long and stiff, and holds erect the big flower. Excellent as a cut flower $\$ 7.50$

SIMPLICITY (Holland Hybrid Cactus) - This was the finest Dahlia imported from Holland in 1916. Color a clear pale lilac. Stems extra long

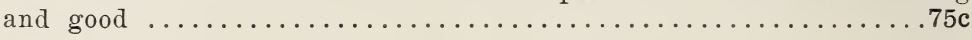

†SNOWDRIFT (California Cactus)-Considered by our growers the finest white cactus in cultivation; a splendid flower for decorations..... \$1.50

SOVEREIGNTY (English Cactus)-One of the largest Cactus Dahlias. Plants are strong growers and produce a long succession of fine blooms. Color is pure rellow...............................

†STALWART (English Decorative)-Color purplish crimson, round full flower on strong erect stem.................... $\$ 1.50$

STERNA (Holland Paeony Decorative)-One of the most beautiful Dahlias that ever came out of Holland. In color it is a pale sulphur white with a lovely yellow center. The stem is of the best, the blooms are alwars perfect and the shape evervthing that could be desired. The petals are

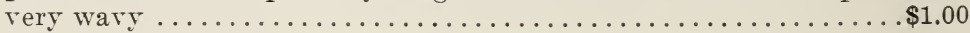


Stock limited on varieties marked $\dagger$

STARTLER (English Decorative)-One of the largest in this section. It has a fine erect habit, and is a very free flowering, producing blooms often ten inches across, of a pleasing scarlet color. It has very long flower stalks and is extra good in every way............. \$1.00

ST. LEONARD'S (English Cactus)-Color at base and half the length of petals is a beautiful shade of yellow, balance of petals and tips is a bright scarlet. Flowers stand boldly erect and are very hardy, being the last to be cut down by frost. I consider this one of the very best English Cactus Dahlias I have ever imported...............

SULPHURIA (English Decorative)-One of the earliest to bloom. Sulphur yellow, with long petals throwing back like a Japanese chrysanthemum. Blooms are large and very free. A variety that has come to stay...50c

SUSSEX (English Cactus) - This variety has the narrowest florets of any in our collection, and yet withstands bad weather conditions better than many of the coarser sorts. Flowers are far above the average width and of flattish form, but the petals slightly and evenly incurve at the tips. Habit very fair, the stems being long. Color clear light yellow. $\$ 1.00$

SWEETBRIAR (English Cactus)- In exquisite shade of rose pink. The finest pink Cactus Dahlia on the market..................

†TACOMA (Washington Decorative) - A full decorative on a strong stem. Color same as Geisha. A particularly good flower............ \$1.00

TERRA COTTA (Holland Decorative)-A large full flower of the true Holland type, with graceful wavy petals and always full to the center. It has a grand stem and is always a mass of bloom ............75c

TIARA (English Cactus) - Orange red, distinct yellow zone at base of petals. Large incurved flower, narrow florets, good stem........50c

†TITIAN (English Paeony)-A particularly lovely variety on long strong stems. Very large. Color is shaded rose......................

TOM LUNDY (California Hybrid Cactus) - A very large California variety on good stem. Color is deep crimson. Very satisfactory.........75c

†TRANSPORT (English Decorative)-One of the strongest stemmed Dahlias. Color is creamy yellow in center to soft pink on outer petals..... \$1.00

TURNER (English Paeony) - This is one of the finest Paeony Dahlias ever introduced, being a lovely shade of pink that is always admired. Good

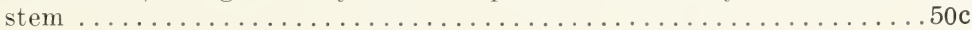


Stock limited on varieties marked $\dagger$

UNION JACK (English Cactus)-Bright red, shaded and tipped white. Without doubt the finest tipped variety in commerce. Very free

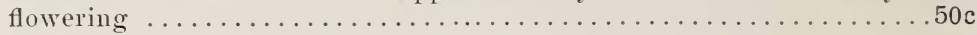

VALIANT (English Cactus) - One of the finest Cacti introduced in years. A giant flower of brilliant crimson, carried on a giant stem. Perfectly incurved, florets long, narrow and intermingled.............\$1.00

VAN DYKE (English Paeony)-Probably the most popular of all Paeony Dahlias. Flower is very large on a long strong stem. Color is salmon shaded heliotrope. Petals are most artistically arranged and it always pleases . . . . . . . . . . . . . . . . . . .

VETERAN (English Cactus) - A Dahlia of first-rate habit, and remarkable for its long succession of good well formed flowers, carried on splendid stems. Color crimson scarlet. This is a full sized cactus, with the

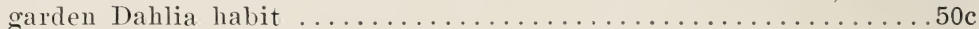

VICAR OF WASPERTON (English Cactus)-According to Ridgway's color chart there are three shades of pink in this exquisite flower. The base of the petals is a beautiful alizarine pink with an overlay of yellow, blending to a shade of rosolane pink with and edging off to a delicate cameo pink. The center of the flower is a charming primrose rellow. This new ereation is one of the best of the English importations, having gigantic size and being ideal for exhibition purposes. The florets are very long, tightly quilled and beautifully incurved..........\$1.00

VULCAN (English Cactus) - A remarkably full and large English flower. Color deep maroon, and at base of each petal there is a tiny white petal, which adds to the beauty of the bloom. Good stem...........\$1.00

†W. D'ARCY RYAN (California Decorative)-Color violet purple heavily striped white. Large flower and free blooming............\$1.00

WODAN (Hybrid Cactus)-Immense flower on a good stem. Color is salmon rose. A rery satisfactory Dahlia-quite one of the best........50c

W. W. RAWSON (Show)-A wonderfully quilled Dahlia of great beautr. Good stem. Color is white, overlaid with delicate lavender......50c

YELLOW KING (Holland Hybrid Cactus)-One of the very largest of its class on long strong stems. Color is chrome vellow. It is fittingly

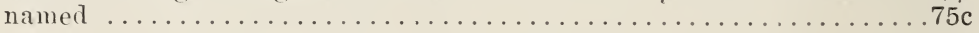


Stock limited on varieties marked $\div$

\section{PON-PON DAHLIAS}

ANNIE DONCASTER Soft yellow, edged maure.................

BELLE OF SPRINGFIELD Dark brick red...............25

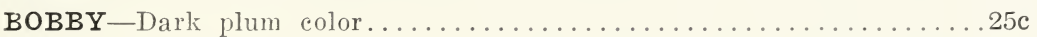

DARKEST OF ALL_Dark maroon, almost black.............25c

DR. JIM-Lavender, edged cerise purple.................50c

ELEGANTE-Soft silvery pink shaded darker..............25c

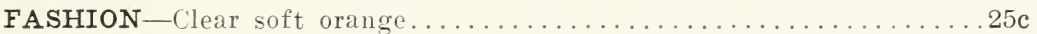

GRUSS AM WIEN--Crushed strawberry ..............25c

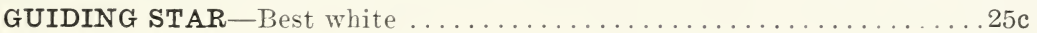

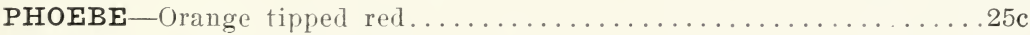

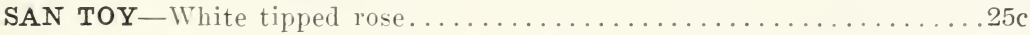

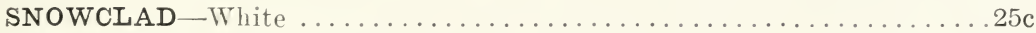

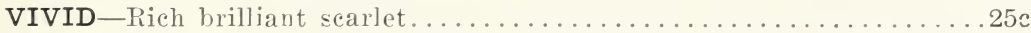




\section{Stock limited on varieties marked $\dagger$}

\section{STAR OR COSMOS DAHLIAS}

This is a new and interesting type of the Single Dahlia recently perfected in England. The flowers are "star petaled" and about the size of a Cosmos blossom, which they resemble. They are more useful for cutting, being borne on stems often two feet long, the plants being remarkably free blooming, lasting for a long period when cut and extremely showy in the garden.

AUTUMN STAR_Autumn shades. Very pretty and desirable.......25c

CRAWLEY STAR-Lovely shade of clear rose pink, darker in center. Particularly lovely by artificial light..................

EVENING STAR_Beautiful Venetian pink................

IFIELD STAR $-A n$ odd shade of $\operatorname{shrimp}$ pink $\ldots \ldots \ldots \ldots \ldots \ldots$

MORNING STAR-A lovely shade of pink, darkening to maroon in center $25 \mathrm{c}$

NORTHERN STAR-A distinct shade of satiny rose............25c

WESTERN STAR-Apple blossom pink shading to white.........25c

WHITE STAR-Pure white with rich center of orange yellow, closely resembling a water lily ............................

WORIH STAR-A pleasing shade of old rose, with white bars down the

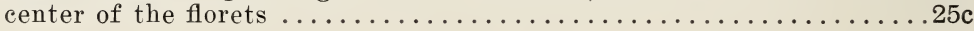

YELLOW STAR - A charming shade of soft primrose yellow. Delightful for table decoration. A fine companion for the pink and white va-

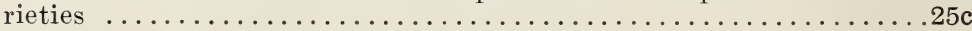

AMI BARILLET (French Star Dahlia)-Bright deep scarlet, with darker

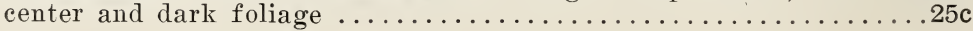






\section{CULTURAL DIRECTIONS}

Dahlias are easily grown, requiring no special soil, treatment or skill to bring them to perfection.

They are really an Autumn flower and should not be planted too early.

They are remarkably free from disease and have few special enemies.

Plant in sunny situation, although they will do nicely in partial shade.

Prepare the soil by deep spading; if soil is sandy a shovel full of well rotted manure may be incorporated with it; if otherwise use little, if any, fertilizer before plants begin to bud. Add sand or coal ashes to heavy soil.

Drive a stake in each hole to support the plant. Lay tuber down flat with eye upward and next to stake, about six inches deep, and cover two inches with pulverized soil, gradually filling to level as plant progresses.

As soon as plants are large enough, pinch out the top just above the second or third set of leaves; this causes the plant to branch.

Cultivate well until buds appear, then stop all cultivation except light raking after rain or watering, just enough to break the crust of ground; only be sure and do this.

When buds appear spread manure or some fertilizer around plant and rake lightly into the soil.

Sometimes a perfectly good tuber with a good eye will refuse to sprout, in such cases, dig uo the tuber and soak for $2 t$ hours in fresh water, this usually will case it to sprout in a reasonable time after replanting.

Unless weather is very dry and hot, do not begin watering until buds appear, then soak the ground thoroughly (not sprinkle) about once a week or ten days. Cut off all faded flowers with as much of the stalk as you can.

For extra large blooms disbud by pinching off all the buds in a cluster except the strongest one.

If bothered by cut worms or slugs, cut a piece of tarred paper 3 inches wide by 10 or 12 inches long, form collar and place around plant, one inch below and two inches above ground.

For cut flowers pick in the evening or early morning if possible; burn the ends of stems in any flame, or dip in boiling water for 10 seconds; after either treatment place in cold water and put in cool place free from draft until wanted.

When frozen down in Autumn, cut stalks off at the ground and dig carefully so as not to break neck of tuber, for the eyes for next season's growth are only found where the tuber joins the stock. Store same as potatoes where they will not freeze, shrivel or rot. Turn the clump upside down to drain out any moisture that may start decay. 


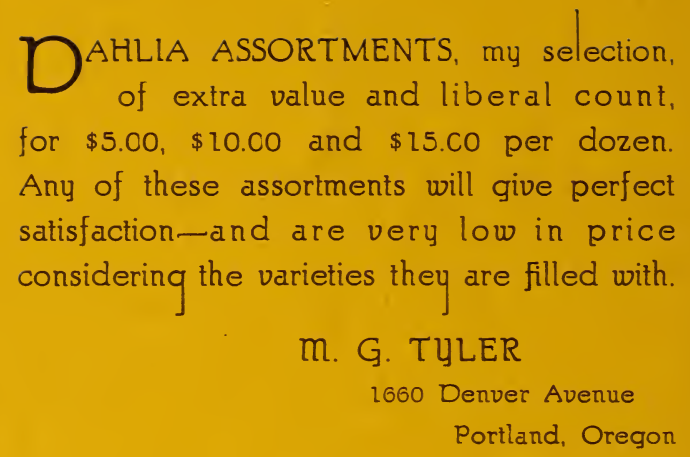

member:

The American Dahlia Society.

National Dahlia Society of Great Britain.

Societe Mationale d'Horticulture de France.

Nederlandsche Dahlia Vereeniging, Holland

The Dahlia Society of California. 